\title{
THE EFFECTS OF THE INTEGRATED APPLICATION OF BSC AND ABM TO ENTERPRISE STRATEGY AND EFFICIENCY
}

\author{
Violeta Domanovic* \\ Faculty of Economics, University of Kragujevac, Kragujevac, The Republic of Serbia
}

\begin{abstract}
The shortcomings of an individual application of some managerial innovation models in the domain of management accounting and strategic management in the modern business environment made research into the complementary and integrated application of managerial innovation models inevitable. The aim of the research is to show that the complementary use of the BSC and the ABM in managing enterprise strategy and efficiency eliminates the shortcomings of their individual application. The paper specifies the effects of the application of the BSC and the ABM on the enterprise strategy, particularly emphasizing the role of ICT in the course of implementation, and presents the results of the empirical research into the correlation of the BSC and the ABM regarding the strategy and efficiency of an enterprise. Despite possible problems and limitations, a proper synergic use of respective managerial innovations enables a better implementation of the defined strategies and improves the efficiency of the enterprise in the long run.
\end{abstract}

Keywords: BSC, ABM, strategy, information and communication technologies, enterprise efficiency

JEL Classification: M10, M21, M41

\section{INTRODUCTION}

Performance management systems include various organizational activities that managers apply in order to make their employees focus on strategy implementation (Otley, 1999). Performance measurement systems make enterprises plan and coordinate the activities performed by their employees by providing the exact and opportune feedforward and

\footnotetext{
* Correspondence to: V. Domanovic, Faculty of Economics, University of Kragujevac, Dj. Pucara 3, 34000 Kragujevac, The Republic of Serbia; e- mail: vterzic@kg.ac.rs
}

feedback on how to operate, encouraging a different behavior when necessary (Anthony \& Govindarajan, 2007). Defining and implementing a strategy becomes significantly complicated in a situation when an enterprise seeks to achieve cost efficiency, on the one hand, and offer customers products and services of a high quality, just in time, and with reliable delivery, on the other (Chenhall, 2003). Nowadays, enterprises adopt the strategic performance measurement systems that enable the formulation and successful implementation of the defined strategy. J. Bisbe and R. Malagueño (2012, 296-311) examine whether strategic performance measurement systems have an effect 
on organizational performance by defining strategic issues and strategic decisions regarding the process of (re)formulating strategies. J. Bisbe and R. Malagueño $(2012,309)$ point out that there is "a link between strategic performance measurement systems and organizational performance when the environment dynamism is low, but not when the level of dynamism is high".

The significant factor in the implementation of strategic performance measurement systems is information and communication technology. The introduction and implementation of new management systems and information systems have become essential for the survival of the enterprises striving to meet the challenges of the global market. New measurement and management systems have grown in isolation from other initiatives and systems, resulting in repetition, discrepancy and inadequate communication. Due to the lack of an integrated model, these initiatives have failed to provide all the promised benefits. Information integration is essential for the optimal use of enterprise resources. The integration of cost management and performance management models provides a better information basis for decision making.

The subject of the research conducted in this paper is the synergistic use of strategic performance measurement systems, such as the BSC and the ABM, as a managerial innovation in today's business environment.

The main goal is to show that deficiencies in the elaborated managerial innovation can be removed by their complementary and integrated application.

Bearing in mind the defined subject and the research goal, the starting hypothesis is that the integrated application of the BSC and the ABM, with adequate software support, significantly contributes to the efficient implementation of the defined enterprise strategy and efficiency.

In order to verify the defined hypothesis, a qualitative methodology has been applied. The method of synthesis and induction and the empirical studies of different authors on the correlation between the BSC and the ABM are used to synthesize different positions, on the basis of which a general conclusion is derived regarding the impact of the $\mathrm{BSC}$ and the $\mathrm{ABM}$ on enterprise strategy and efficiency.

In that sense, the paper first discusses the effects of the BSC and the ABM on enterprise strategy. Then, the significance of information and communication technology on the process of implementing the BSC and the ABM are elaborated. Ultimately, the paper provides the results of the empirical research in the correlation between the BSC and the ABM and enterprise efficiency. The corresponding conclusion is finally drawn and a position is taken on the validity of the starting hypothesis, which, in methodological terms, establishes a connection between the subject and the purpose of the research. The concluding remarks also highlight the theoretical and practical implications of the research, identify the perceived limitations and propose the direction of future research.

\section{THE INFLUENCE OF BSC AND ABM ON ENTERPRISE STRATEGY}

A strategy is a significant determinant of the success of an enterprise. The problem, however, does not occur in the process of the strategy formulation and development, but in the implementation phase. The BSC describes the strategy and parses it to individual parts in terms of the targets and the business success measures classified into four perspectives - the financial, the customer, the internal business processes, and the learning and growth perspectives. The BSC is ideally created by understanding and translating a strategy into objectives, measures, targets and initiatives for the realization of the defined goals and tasks from all perspectives. The BSC leads to zerodefect production. Employees are able to focus their energy and daily activities on a crystal clear objective - products and services free of defects, rather than on thinking about what constitutes a truly world class. By applying the BSC, as a model for translating a strategy into an action, enterprises create a new measurement language, which directs their employees towards fulfilling the defined objective. 
The key element of the definition of a strategy is the implementation of very distinct activities in relation to competitors. In such a way, the enterprise has an ability to make a distinctive customer value proposition, thus differentiating itself from its rivals. This must be expressed in the BSC and has to be compared with the strategy of the enterprise. Thus, if an enterprise wants to differentiate itself by building a close relationship with its customers, then the BSC should reflect this strategic direction. After that, different performance measures need to be defined from different perspectives, which collectively affect the strategy implementation. The measures relating to services to target customers should be emphasized in the customer perspective and connected with the metrics in the internal business processes perspective and the learning and growth perspective. It is assumed that this chain of related measures, which reflect the activities of the selected enterprise, affects the growth of revenues and profits in the financial perspective. Once again, the BSC is an instrument to describe and articulate the activities which distinguish a particular enterprise from its competitors.

The BSC and the strategy go hand in hand. Regardless of whether the BSC is used to assess enterprise efficiency or not, it represents a powerful model to guide managers towards meeting strategic objectives. In accordance with this, R. Kaplan and D. Norton (2001, 42-43, 139) develop the strategy map concept, which uses the BSC for a detailed description of a strategy, using causal diagrams. A simple strategy map is shown in Figure 1. The strategy map links all the four perspectives of the BSC, showing how measurable objectives in each perspective contribute to performance in the next perspective. The strategy map begins with the learning and innovation perspective, which includes employees' competences, strategy awareness and the technology infrastructure as objectives. These objectives directly contribute to the internal business processes perspective, where employees apply their competences and strategic awareness and use the technology infrastructure. Similarly, the objectives from the perspective of daily business activities are complementary to the goals of the customer perspective. The goals from the customer perspective are complementary to the objectives of the financial perspective. As each enterprise has a different BSC, each has a different strategy map. A strategy map is a detailed overview of how the enterprise achieves its strategic goals, showing an interaction among the perspectives in a BSC (Kaplan \& Norton, 2001).

strategy map supports the idea that the financial performance and shareholder value are the ultimate goals in the numerous cases of the application of the BSC. All other perspectives directly contribute to the ultimate financial goals. In fact, non-financial measures in other perspectives are good forecasters of subsequent financial performance (Ittner \& Larcker, 1998, 1-35). The strategy map emphasizes the fact that the BSC, describing in detail the strategy of an enterprise, can be used as an instrument for the strategy development and the assessment of the dynamics of the realization of the defined strategy.

The BSC finds its information support in ActivityBased Costing (ABC). The concept of Activity-Based Costing and Activity-Based Management (ABM) facilitate strategic cost management. This concept does not only show how activities consume resources

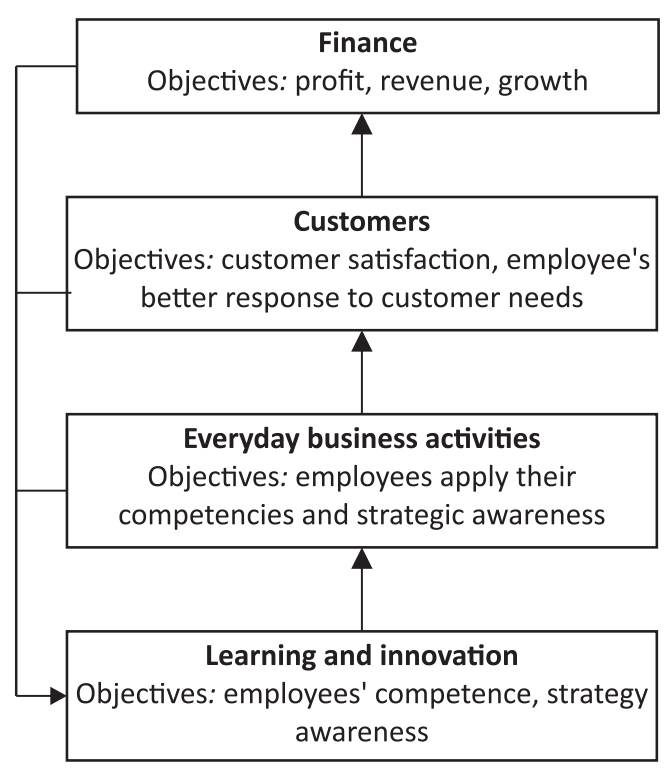

Figure 1 Strategy map based on BSC

Source: Author, based on: Blocher, Chen, Cokins \& Lin, 2005, 742 
and how products or customers cause activities, but also allocates costs to products and activities based on the resources consumed. The $\mathrm{ABC}$ describes an enterprise as a series of activities created to fulfil customer demands. The $\mathrm{ABC}$ provides managers with information to be used in activity management in order to improve competitiveness and achieve strategic goals. The ABC and the BSC are two contemporary and complementary concepts (Kaličanin \& Knežević, 2013, 114). Đ. Kaličanin and V. Knežević $(2013,114)(2013,114)$ point out that these concepts are directly correlated if the BSC includes all relevant information pertaining to the competitive advantage of an enterprise. This means that it includes information derived from the ABC. It is logical that most of the objectives and measures are defined precisely based on the financial perspective. The common goals in this perspective are revenue growth, increased productivity and lower costs. Since they are defined in an aggregate form, it is necessary to formulate goals and measures from the internal business process perspective, where value is made. As internal business processes consist of activities, the $A B C$ is a necessary support for the analysis of the costs and effects of these activities.

Strategic choices determine activities. Successful enterprises spend their resources on the activities that lead to the biggest strategic advantage. Through measuring the costs of activities and identifying activities, the $A B C$ and the $A B M$ help managers understand the relationship between the strategy of an enterprise and the activities and the resources necessary for the implementation of the defined strategy.

The $A B C$ and the $A B M$ are critical for the enterprises that follow the cost leadership strategy in order to gain a competitive advantage, because critical activities, cost drivers and ways to improve processes in order to reduce costs are identified by them.

These concepts are also helpful to the managers who adhere to the differentiation strategy as they identify opportunities to increase value, develop the customer strategy, support the technology leadership strategy and establish the pricing strategy by identifying and analyzing the key activities, processes, cost drivers and methods of improvement.
Generally speaking, the $\mathrm{ABM}$ and the $\mathrm{ABC}$ provide answers to questions in the domain of strategic cost management, facilitate the best strategy identification and assist in the realization of strategic goals (Blocher et al, 2005, 162):

\begin{abstract}
"How are cost structure and profits related to the competition? How does a shift from volume-based costing to activity-based costing reflect on pricing, product design, manufacturing technology and a decision on the production line? What are the effects of costs on different products when the enterprise adopts a new strategy; for example, when it shifts from the mass production of standardized products to small-series production in order to match customer preference? Has the enterprise adopted the most costeffective distribution system for its products? How will changes in activities and components affect suppliers and customers in the value chain? How will changes in business processes affect the final result? What are potential cost savings if the enterprise applies the ABM in order to detect low-value-added activities and implement a low-cost strategy? How can the ABC and the $\mathrm{ABM}$ assist enterprises in implementing changes in order to achieve competitive performance strategies and short lead time in the delivery of their products?"
\end{abstract}

Performance management systems should be in line with the strategy. The enterprises that choose a cost leadership strategy opt for performance management systems, which are based on "conservative organizational culture, centralized organizational structure, specialized and formalized working procedures, simple coordination mechanisms, formal, financially-based strategic planning, short-term budgeting" (Stojanović Aleksić, 2008, 150-159; Adler, 2011, 260). The enterprises that adopt a differentiation strategy create performance management systems based on "entrepreneurial organizational culture, decentralized organizational structure, non-standard working procedures, complex coordination systems, quality-based strategic planning, a long-term budgeting system" (Adler, 2011, 260).

Starting from the enterprise's mission, vision, values and strategy, the BSC is made at the highest level - the corporate scorecard. The corporate scorecard contains a series of related targets and measures, and, on the basis of a cause-and-effect relationship, reflects 
the strategy. Focusing on the corporate scorecard, scorecards at lower levels have been created in the enterprise. This enables top managers to gain an insight into how much managers at lower levels and individual employees contribute to the realization of corporate goals. Initiatives in all scorecards require the resources distribution as the basis for the budget proposal (Niven, 2002, 229).

With the BSC, as a guide, managers require feedback from and the involvement of their employees in the preparation of the budget. The BSC introduces a completely new management model, where strategy is at the center of the organizational universe, rather than financial control. Financial control would be suitable for the organizations engaged in reducing expenses, setting targets, controlling the actual performance based on target values and taking measures to improve the performance of the inefficient management team (Micheli, Mura \& Agliati, 2011, 1117). In cost management systems, flexible budgeting is considered as a means of controlling overhead costs. In contrast, the system of strategic control, such as the BSC, places a greater focus on the key success factors and the application of the financial and non-financial indicators for a more efficient translation of strategic plans into action (Micheli et al, 2011, 1117).

\section{INFORMATION AND}

\section{COMMUNICATIONS TECHNOLOGIES FOR THE IMPLEMENTATION OF BSC}

\section{AND ABM}

Efficiency measuring is a process that evolved as enterprises changed their business processes in accordance with the requirements of the modern business environment. In the 1960s and the 1970s, enterprises used financial measures in order to assess their efficiency. In the 1980s, enterprises in the United States extended the scope of the examined measures, although the majority was based on short-term accounting and financially based measures, which were less competitive in comparison with the measures used in enterprises in Japan and Europe. In the 1990s, the BSC was introduced, which was considered as a major innovation in performance measurement. The
BSC has "quantified and incorporated non-financial information in the measurement reporting system, making it consistent and significant" (Swamy, 2002, 44).

Since the late 1990s, enterprises have expanded their operations chains, since the Internet has taken the irreplaceable role in conducting business operations. Thus, Web Analytics became significant with respect to the measurement and assessment of business performance. Web Analytics is the analysis of a website data, which enables the assessment of the success of a website and the comprehension of customer conduct and action. Thus, an enterprise could collect information on customer tastes, feedback and demographic information so as to enable a boost in its revenues and to reduce its costs (Swamy, 2002, 44). In today's business environment, enterprises must make a "real mixture of traditional performance measures, support them with Web analytics and connect them with a vision and a strategy in order to produce a holistic view of organization" (Swamy, 2002 , 46). In the 21st century, the BSC consists of two more perspectives, namely the e-Business and the User perspectives.

In the traditional BSC, the electronic business perspective links the targets from the customer and the financial perspectives and concentrates on higher profits and a market share. This perspective includes financial measures as well as market measures, based on "user interaction with Web-based technology". The users of a Web-based system could be outward customers, inner employees, suppliers and partners. Regarding the electronic business perspective, it is necessary to analyze the types of the processes within Web-based initiatives and their primary purpose. The customer perspective is fit for the internal and the learning perspectives in the traditional BSC. The selection of metrics for this perspective imposes the consideration of the processes that improve efficiency, as well as the way in which customers evaluate these processes (Swamy, 2002, 47).

Starting from the requirements strategic and operational management impose on the modern enterprise, for the successful implementation of the BSC and the ABM, it is necessary that these 
management and measurement systems should be automated. This is not only done for data updating, but also for preparing and disclosing reports. The user of Web-based system could be outward customers, inner employees, suppliers and partners. BSC means too much time and too many endeavors. The research „results indicate that $70 \%$ of organizations that have adopted the BSC and the ABM use some type of software in the implementation process to reduce effort” (Lawson, Stratton \& Hatch, 2004, 40). „Of these organizations, $31 \%$ apply off-the-shelf software, $43 \%$ apply in-house software, and $27 \%$ of organizations use both" (Lawson et al, 2004, 40).

The need for the introduction of software in the process of applying the model of the BSC and the ABM increases with the size of the enterprise. Small enterprises do not apply software in the process of the implementation of the BSC and the ABM (59\%) (Lawson et al, 2004, 40). This percentage reduces as the category of the enterprise increases. The same applies to offthe-shelf and in-house software. The percentage of the enterprises that apply it increases with the size of the enterprise. The main advantage of software application is reflected in saving time, which would otherwise be spent on the activities that do not increase value. Software encourages changes in business processes. The introduction and application of software, however, has its price. In addition to implementation and maintenance costs, the price includes a compensation for the right to use (a license). At the beginning of the BSC and the ABM implementation, the enterprise can start with a relatively simple system. Over time, however, managers become aware of the limitations of the traditional system and are willing to include more advanced systems. It is worth mentioning that "the most commonly used packages are Hyperion's Performance Scorecard and OROS" (Lawson et al, 2004, 41).

One of the most desirable system characteristics for the implementation of the BSC and the ABM is report design flexibility. The implementation of the BSC and the $\mathrm{ABM}$ is an iterative process. Most managers feel that they have enormous measures or no exact measure. The fact that an enterprise has a variety of measures does not guarantee that it has chosen the right one.
Gradually, after receiving feedback from customers, managers conclude that some measures are redundant and that some are missing. Flexibility is a significant characteristic in the process of the BSC automation. Enterprises can develop the Enterprise Resource Planning (ERP) systems; install the computers "that could be used by everyone and that could perform very complicated tasks, or install some other systems" (Lawson et al, 2004, 42-43).

\section{ERP system vendors claim to offer}

\begin{abstract}
"an integrated solution for the planning, implementation, and control of business processes horizontally along the value chain SAP R/3 (the market leader) integrates processes such as the planning of sales and materials, production, warehouse management, financial and management accounting and human resource management" (Norton, 1999, 38).
\end{abstract}

Strategic Enterprise Management Systems (SEMs) allow for a strategy formulation and implementation by using the BSC, a strategy evaluation through value drivers and operational management through monitoring performance, making business plans, the consolidation of business plans and communication with stakeholders.

SEMs tend to connect performance measurement and control with strategic targets in trying to verify the complete focus of operational decision making on defining strategic targets (Fahy, 2001, 173). In order to qualify as a SEM, a system should have the following attributes (Brignall \& Ballantine, 2004, 229):

\footnotetext{
„it should be built on ERP systems; SEMs should be based on data warehousing tools, such as ABM cost centers; SEMs include various integrated models, including ABM, BSC and other business reporting and analysis models; these systems have an internal and an external market focus as well, and give help in the strategic decision-making process".
}

The market leader in ERP systems, SAP AG, offers an integrated system for SEM, containing five major applications and the related tools (Brignall \& Ballantine, 2004, 229): „Business Planning and Simulation (BPS), Business Consolidation (BCS), 
Corporate Performance Monitoring (CPM), Business Information Collection (BIC), Stakeholder Relationship Management (SRM)". Figure 2 illustrates how SAP's version of SEM underpins strategic change management and strategic management processes on the basis of the fundamental BSC model.

The $A B C$ and the $A B M$ are the information basis of the BSC. The successful and easier implementation of the $\mathrm{ABM}$ model requires the introduction of appropriate software. Software packages are available, robust, and easy to use, being subject to continual development.
Such software is designed to facilitate the construction of large-scale models of high complexity, facilitating cost allocation at the same time. ABM software is used to store information regarding the full assortment of finished products and work-in-progress made or sold. These models could be connected with the budgeting systems and the systems for reporting on actual versus budgeted performance. Also, these models enable the fortifying of the selling price and the making of other business decisions. The ABC could be related to the inventory control systems in order to provide the inventory assessment.

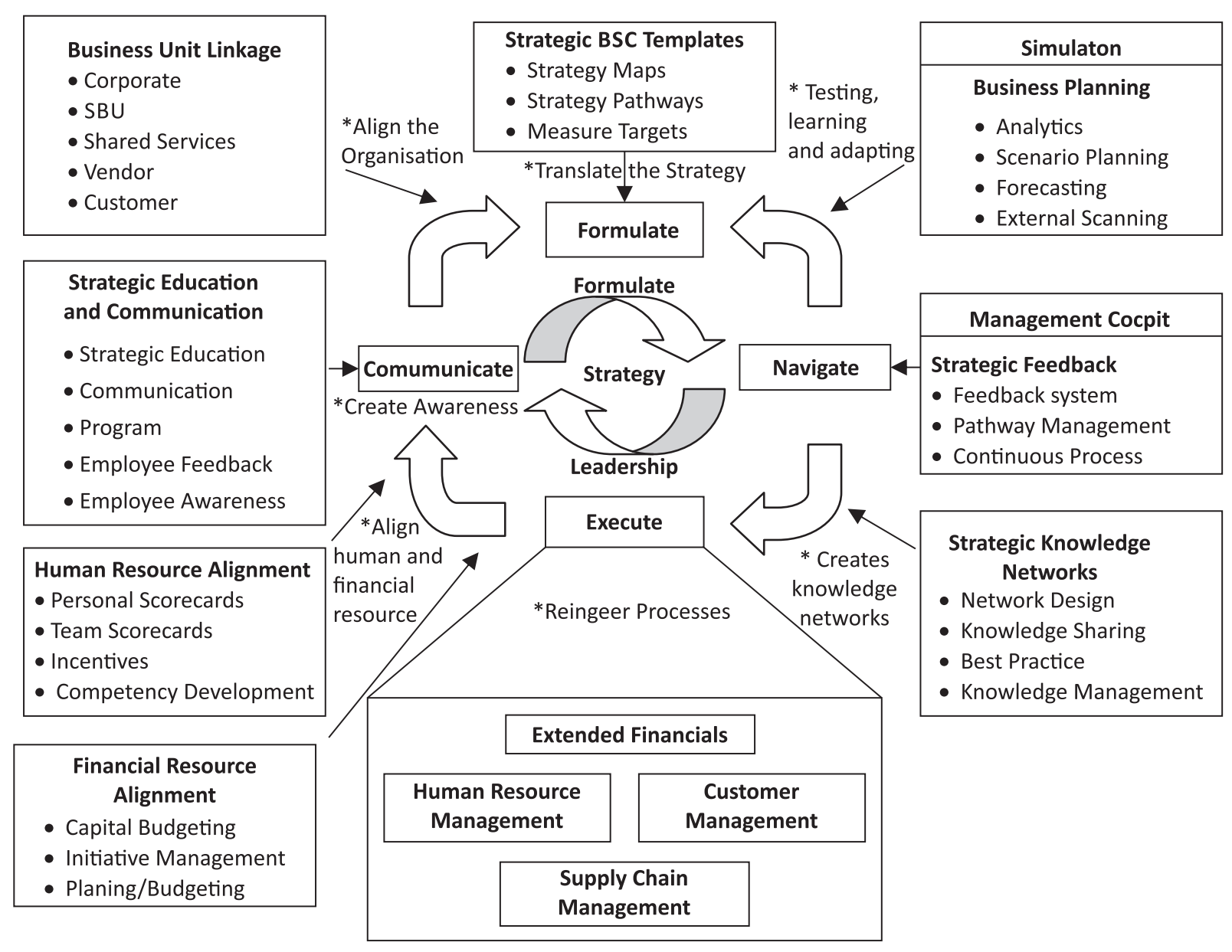

Figure 2 SAP's version of BSC model 


\section{THE EMPIRICAL ANALYSIS OF A CORRELATION BETWEEN BSC, ABM AND ENTERPRISE EFFICIENCY}

Since the early 1980s, researchers in the field of management accounting have been describing the escalating insignificance of traditional performance measures and control models. The disadvantages of these systems are reflected in the inability to connect „performance measurement to the strategic initiatives of enterprises", with an emphasis on „external reporting rather than accounting reports useful for internal decision making" as well as in the failure to track the progress in technology, changing in line with the operations of production enterprises. The characteristics of the contemporary business environment have imposed an urge for the introduction and implementation of alternative performance measurement and control models.

The BSC was created as a result of the urge for making the management accounting functions - planning, control and performance measurement - better. A. A. Atkinson, R. Balakrishnan, P. Booth, M. J. Cote, T. Groot, T. Malmi, H. Roberts, E. Uliana and A. Wu (1997, 79-108) state that the BSC model has so far taken a significant place and role in management accounting. However, there are a small number of studies on how this concept affects the financial performance of enterprises, and it is insufficiently emphasized that the BSC is better in comparison with other performance measurement systems. The primary principle of the BSC is that success is primarily achieved based on the key non-financial measures, not on financial measures.

The $A B C$ and the $A B M$ have been advocated as the foundation for making strategic decisions and increasing a profit performance for more than a decade. The $A B C$ information is broadly used for the evaluation of the continual improvement and control of the process performance. Although this concept has quickly been accepted, there are diverse opinions regarding its effectiveness, usefulness, relevance and practical applicability. Despite the fact that managers insist that management accounting systems should undergo a cost-benefit analysis, there is still no institutionalized empirical evidence of the validity of the benefits of the ABC. For this purpose, empirical evidence on the financial effects of the implementation of the ABM is needed.

T. Kennedy and J. Affleck-Graves (2001) empirically prove that the implementation of the $\mathrm{ABC}$ significantly improves the relative performance of the enterprise, judging by both the market and the accounting measures. A study by S. A. Maiga and F. A. Jacobs-a (2003, 283-301) can be used to elaborate on the empirical analysis of the correlation between the $\mathrm{BSC}$, the ABM and financial performance. What is of special importance is the impact of the integrated application of the BSC and the ABM on the efficiency of business operations. In order to examine the effects of the interaction between the ABM and the BSC, one variable is used to measure the $\mathrm{ABM}$ and four to measure the BSC.

ABM measures: In order to reach the desired quality in the implementation of the $\mathrm{ABC}$, the variables most closely connected with the success of this concept, precisely those that most often appear in the implementation process, need to be considered. M. D. Shields $(1995,148-166)$ was the first to conduct an empirical study, proposing some "organizational and technical factors" linked with the ABC success. The author states that the $A B C$ is significantly correlated with several application categories: performance measurement, the activity analysis, product costing and reengineering. In addition, he finds that there is a significant correlation between a success and the percentage of the costs processed in the $\mathrm{ABC}$. Hence, the variables discussed herein are associated with $\mathrm{M}$. D. Shields's basic framework. Specifically, the data on the six $\mathrm{ABC}$ variables are collected (Maiga \& Jacobs, 2003, 288):

"(1) top management contributions, (2) an agreement on tasks, (3) a connection with a ruthless strategy, (4) a connection with a quality initiative, (5) confidence that the $A B C$ system could be practically applied by all the employees in the organization, not just by the Accounting Department and (6) the evaluation of performance/remuneration (which is supposed to be nearly related to the favorable outcome of the $\mathrm{ABC})^{\prime \prime}$. 
M. D. Shields and M. A. McEwen (1996, 15-22) cite the seven $\mathrm{ABC}$ implementation success factors, these being as follows:

"the top management support; a connection with a competitive strategy, highlighting the quality and the Just-in-Time system/speed; a connection with the evaluation of performance and compensation; employee training; non-accounting proprietorship, adequate resources and the agreement on and the distinctness of the ABC targets".

BSC measures. According to R. S. Kaplan-a and D. Norton $(1992,71-79)$, the BSC is measured by using some variables from the basic four perspectives. The customer perspective contains eight variable measures: "the customer response time, the customer content, the number of customer reclamations, the on-time delivery, the delivery lead time, the number of the returned deliveries because of the bad quality, overhaul costs, warranties and the market share". The perspective of internal business processes includes six variables: "the production lead time, the ratio of a good output to the total output, the variance of the workforce efficiency, the variance of material efficiency, the level of the material waste, the percentage of the defective delivered products". The learning and growth perspective implies three variables: "the number of new patents, time to market, the number of new products launches". From the perspective of finance, three variable measures have been defined: „return on investment, sales growth, the operating profit". Enterprise performance is evaluated according to the following dependent variables: "the product quality, customer satisfaction and the net profit rate".

In order to obtain more valid results, it is necessary to include some control variables, such as the size of the enterprise. Some authors believe that small businesses often stay away from innovation not because of the resources deficit but because of the recognized resourced deficit. Conversely, large enterprises have more funds and management expertise. S. A. Maiga and F. A. Jacobs $(2003,289)$ point out that:

"there is no statistically significant relationship between the size of the enterprise and the decision on the adoption of $\mathrm{ABC}$ and $\mathrm{ABM}$, that there is no correlation between the size of the enterprise and the number of changes in management accounting, but that there is a positive correlation between the size of the enterprise and elaborated management innovation".

In order to prove that the $\mathrm{ABM}$ and the $\mathrm{BSC}$ are significantly correlated, a hierarchical regression analysis is applied. The following regression models are derived to verify these proposals (Maiga \& Jacobs, 2003, 291):

„Organizational performance (the customer content, the quality of the product and the net profit rate $)=\alpha_{0}+$ $\beta_{1}$ Size $+\beta_{1}$ Customer $+\beta_{2}$ Internal business processes + $\beta_{3}$ Learning $+\beta_{4}$ Finance $+\beta_{5} \mathrm{ABC}+\varepsilon . "$

"Organizational performance (the customer content, the quality of the product and the net profit rate) $=\alpha_{0}+\alpha_{1}$ Size $+\beta_{1}$ Customer $+\beta_{2}$ Internal business processes $+\beta_{3}$ Learning $+\beta_{4}$ Finance $+\beta_{5} A B C+\beta_{6}$ CUSTOMER ${ }^{*} \mathrm{ABC}+\beta_{7}$ Internal business processes* $\mathrm{ABC}$ $+\beta_{8}$ Learning ${ }^{*} \mathrm{ABC}+\beta_{9}$ Finance $\mathrm{ABC}+\varepsilon^{\prime \prime}$,

where the size of the enterprise is expressed by the number of the employees, the $\mathrm{ABC}$ - the degree of the implementation of Activity-Based Costing, $\varepsilon$ - the random error.

The study results point to the fact that each of the four perspectives in the BSC interfaces with the $A B C$ in order to influence performance. However, no significant positive interaction was observed between internal business processes in the BSC and the ABC in order to influence the net profit of the enterprise. Theoretically and empirically speaking, it is possible to support the view that the BSC and the ABM can have a complementary or synergistic effect on the performance of the enterprise.

Another study worth mentioning in the context of the correlation between the $\mathrm{ABC}$ and the $\mathrm{ABM}$ and the financial performance of the enterprise is the one conducted by D. Cagwin-a and M. J. Bouwman (2002, 1-39). The impact of the ABC/ABM on financial performances is analyzed through this model (Cagwin \& Bouwman, 2002, 5): 
" $\triangle R O I=f(A B C$, the variables allowing the application of this concept, the control variables)"

Where,

$" \triangle R O I$ is the change in the return on investment, measured over the past three to five years";

"The variables that allow the application of the concept of the ABC: information and communication technology, complexity/diversification, the importance of the costs, intra-enterprise transactions, the unused capacity and the competition";

the control variables include the dimensions and the class of the enterprise.

D. Cagwin-a and M. J. Bouwman (2002, 2-3) show the positive synergistic effects of the complementary application of the $\mathrm{ABC}$ and other management initiatives, although it is not explicitly established with which initiative specifically the $\mathrm{ABC}$ generates the greatest benefits to the enterprise. When the $A B C$ is used complementarily with other initiatives, then the net rise in the financial performance achieved by the enterprise is higher than in the case of the application of these initiatives without the ABC. There have been debates, though not proven, that the sum of the benefits of using the $\mathrm{ABC}$ is greater than the costs incurred in connection with it. Furthermore, there are positive associations between the $A B C$ and a rise in return on investment if the $A B C$ is applied in diversified enterprises, in an environment where the low-costs strategy is pretty significant.

S. Davis and T. Albright (2004, 135-153) examine the effect of the individual implementation of the BSC on financial performance. This study aims to examine the effect of the BSC on financial performance. The popularity of the BSC, as the management's instrument connecting employees' actions and objectives with the corporate strategy, has much increased since its introduction in 1992. The authors point to the influence of the application of this concept on the financial performance of the bank. This study is somewhat different from the previous studies (Davis \& Albright, 2004; 136): „although the previous research examines relationships between non-financial measures and performance, it does not seek to establish a connection between the implementation of the BSC and better financial performance; this study uses a quasi-experimental approach to examine the effects of the application of the BSC on organizational performance; the research is based on the actual data on the financial performance of the individual business units in the organization and applies a longitudinal approach in order to determine whether changes in financial performance occur after the implementation of the BSC".

M. A. Malina and F. H. Selto (2001) examine the effectiveness of the BSC in communicating strategic goals and objectives. They conclude that there is an incidental relation between the role of the BSC as the instrument of management control and better performance, as seen by performance measures from the perspective of the BSC. The BSC leads to a better efficiency and profitability. Ittner et al. (2003), in contrast, conclude that there is a negative correlation between the implementation of the BSC and the rate of return on assets as financial performance.

W. B. Tayler (2010) conducts an experiment in order to assess the effects of the implementation of the BSC on the enterprise strategy assessment. The research results show that the managers involved in the selection of performance measures and cause-effect relationships in a BSC can alleviate the optimistic strategy assessment. When managers use data from the BSC for assessing the success of a strategic initiative in whose selection they take part, they assess it as more effective compared to the managers who are not involved in the initiative selection process. W. B. Tayler (2010) emphasizes the importance of cause-and-effect relationships in the BSC. Cause-and-effect relations alone are not a sufficient reason to motivate managers in the process of a strategy assessment. W. B. Tayler (2010, 1112) accentuates that „involving managers in the choice of performance measures, combined with a focus on the cause-and-effect chain, leads to a better assessment of the strategy of the enterprise".

M. M. Cheng and H. A. Humphreys $(2012$, 899) investigate the effect of the key elements of the BSC on the managers' ability to explain the strategic significance of external information and use that 
information for assessing the adequacy of the strategy of the enterprise. The authors find that the presentation of strategic targets, such as strategy maps, in integral connection with the explicit description of causeand-effect relations in the strategy map, increases the relevance of management information and the assessment of the strategy appropriateness. The authors suggest that accountants should have special significance in facilitating managers' strategic actions through the "design and implementation" of effective strategic performance measurement systems. A strategy map allows managers to filter out strategically irrelevant information. In addition, the BSC model increases managers' understanding of the strategic implications of external business trends (Cheng \& Humphreys, 2012, 918-920).

A. A. Mohamed and T. Jones (2014, 1-22) investigate the relationship between strategic management accounting techniques, such as the ABM, and the profitability of the enterprise, and propose a holistic model of profitability based on the interactive and reversible relationship between cost drivers, asset drivers and the enterprise's revenue drivers. In addition to this, the respective model focuses on the balance between financial and non-financial information in profitability management. Such a model identifies strategic information on how enterprises create a profit and where they divert their resources in order to increase long-term profitability. M. Bourne, M. Kennerley and M. Franco-Santos (2005, 373-395) emphasize the importance of the interactive application of performance measures, and claim that performance measurement hinges on the diversity of contextual and process factors.

A. S. Maiga, A. Nilsson and F. A. Jacobs (2014, 85) assess the effect of the interaction of the cost control system, such as the $A B C$, integrated with information and communication technology on financial performance. The study results support the theoretical arguments. Although the main effects of the integration of information and communication technology and cost control systems on the financial performance are not significant, the very integration has a remarkable positive influence on financial performance. The significance of this study lies in the integrated observation of the $\mathrm{ABC}$ and information and communication technology on financial performance.
The previous studies analyzed the isolated impact of the $\mathrm{ABC}$ and information and communication technology on financial performance.

C. X. Chen $(2015,67)$ discusses the strategy testing by using multiple performance measures in a BSC. Internal performance measures promptly indicate problems with the strategy and permit the identification of where and why the strategy has failed.

M. Odar, M. Kavčič and M. Jerman $(2012,445)$ argue that enterprises in the Republic of Slovenia mainly use the traditional models of performance measurement. The modern systems of performance measurement are used occasionally. The authors also emphasize that the implementation of the performance measurement system depends on the different size of the enterprise. Small businesses are almost exclusively reliant on traditional models, whereas large enterprises apply more developed and contemporary models.

V. Domanović (2009) explores the possibilities and effects of the application of the ABM and the BSC in enterprises in the Republic of Serbia and concludes that, in the Republic of Serbia, there are a small number of firms applying the BSC and the ABM. In contrast, enterprises usually apply the traditional model of cost management and traditional budgetary control. As the reason for this, managers generally emphasize the high costs of the introduction and application of appropriate information and communication technology in the process of implementing the BSC and the ABM. Enterprises with an influx of foreign capital apply the BSC as a model of strategic control and performance management and use information from the $A B C$ to build it. Such enterprises conduct a better strategic control, apply better employee incentive mechanisms and identify the individual and sectoral responsibility, which contributes to the improvement of the enterprise's efficiency in the future. V. Domanovic (2013) examines the effectiveness of performance measurement in the contemporary business environment on the basis of the empirical studies by different authors and relying on the original empirical research conducted in renowned enterprises in the Republic of Serbia. V. Domanovic (2013) concludes that the effectiveness of performance measurement systems can be viewed from two perspectives, i.e. through 
enterprise-performance outcomes and employeerelated outcomes. Performance measurement systems, specifically the BSC, should be used as a management instrument for employee motivation, the strategy implementation and the realization of the objectives, i.e. as an instrument "of strategic control and management control" (Domanovic, 2013, 43).

M. Todorovic, Dj. Kalicanin and A. Nojkovic (2015, 45-58) test performance measurement models in enterprises in the Republic of Serbia. The authors find that $18.8 \%$ of the analyzed enterprises apply the BSC, i.e. different types of the BSC. The simplest type combines financial and non-financial measures; the second type includes making strategic maps; the third links compensation systems with the BSC. The authors also point out that the application of a modern performance measurement model, such as the BSC, is facilitated by the introduction and application of appropriate software, which is usually very costly for local enterprises. The introduction and application of modern performance measurement models depends on the size of the enterprise, the level of internationalization and profitability (Todorović et al, 2015, 53).

\section{CONCLUSION}

The modern business environment imposes the need for introducing innovation in the domain of the strategy definition and implementation and in the process of managing enterprise efficiency in the long run. In this context, innovation is introduced in the area of strategic management and management accounting. The two most prominent managerial innovation models are the Balanced Scorecard and Activity-Based Management. Of particular importance is their complementary and integrated application.

The research results confirm the starting hypothesis that there is a high positive correlation between the Balanced Scorecard and Activity-Based Management, on the one hand, and enterprise strategy, on the other. Particularly, the better the Balanced Scorecard and the more refined the Activity-Based Management, the greater the chance that the defined strategy will be consistently implemented and that the expected and higher-than-expected economic effects of its application will be realized. In addition, these concepts can signal a possible failure of the application of the defined strategy, identify the causes of deviations from the established standards, on the basis of which it is possible to define corrective actions and improve the efficiency of the enterprise. Environmental dynamism is an important construct, which remarkably works on the relationship between strategic performance measurement systems and performance, in the sense that there is a strong positive relationship in a stable environment, which becomes weaker in terms of the dynamic environment.

Bearing in mind the results of the numerous studies on the correlation between management innovation, the Balanced Scorecard and Activity-Based Management, and enterprise efficiency, and respecting all their limitations, the general conclusion is that there is a positive correlation between them. In fact, the studies have shown that the enterprises that implement the Balanced Scorecard and Activity-Based Management improve their financial performance - the net profit rate, return on investment and the like. Nevertheless, one should not lose sight of the fact that there are different findings pointing to a negative correlation between these concepts. This is supported by the fact that the very process of the implementation of these concepts requires high costs, and, therefore, in some enterprises of low economic power, the introduction and implementation of these innovation models are not economically justified, as is determined by the cost-benefit analysis. In today's business environment, enterprises must make a real „mixture of traditional performance measures, align them with Web analytics and link them to the vision and the strategy in order to produce a holistic view of the organization". Starting from the requirements which strategic and operational management impose on modern enterprises, and in order to provide an effective implementation of the Balanced Scorecard and Activity-Based Management, these management and measurement systems need to be automated.

There are also indications that the conditions that enable the implementation of the $A B C$ (,the sophistication of information and communication 
technology, the absence of an excess capacity and a competitive environment") affect its efficiency. There is evidence that previously used ActivityBased Costing success measures, satisfaction with Activity-Based Costing and the financial benefits of Activity-Based Costing are the forecasters of an improvement of financial performance. Finally, no studies can definitely determine causality in the given time. Future research could include longitudinal studies investigating the improvement of enterprise performance before and after the implementation of Activity-Based Management.

The scientific contribution of the research lies in a better analysis of the complementariness and the integrated application of management innovation models, such as the Balanced Scorecard and ActivityBased Management. The literature treats management innovation models mainly in isolation, pointing to the limitations and the disadvantages of their use, but little attention is devoted to their integrated application. For modern enterprises, it is of special importance not only to implement certain management innovation models, but also to try to take advantage of a larger number of them. The research results can serve as guidance to managers on how the integrated application of the Balanced Scorecard and Activity-Based Management contributes to the successful implementation of the strategy and the improved financial performance of enterprises.

It is important, however, to point to the following research limitations. First of all, the paper only considers the two most prominent models of performance measurement and management, the Balanced Scorecard and Activity-Based Management in the modern business environment. Studies in the sphere of business economics and management, management accounting and strategic management distinguish among numerous performance management and measurement models, which have not been discussed in this paper. In this context, it is important to observe the integrated application of other performance management models. In addition, the paper has only considered the effects of the Balanced Scorecard and Activity-Based Management on enterprise strategy and efficiency. No effects on employee motivation, stimulation and rewarding have been considered. Third, there are no recent studies on the topic of the integration of the Balanced Scorecard and Activity-Based Management; nor are there those on the effects of their integrated application on enterprise strategy and efficiency. Therefore, future empirical research should focus on the impact of the integrated application of alternative contemporary performance measurement models in enterprises in the Republic of Serbia.

\section{ACKNOWLEDGMENTS}

This paper is a part of the interdisciplinary research Project (No. 41010), which is funded by the Ministry of Education, Science and Technological Development of the Republic of Serbia.

\section{REFERENCES}

Adler, W. R. (2011). Performance management and organizational strategy: how to design systems that meet the needs of confrontation strategy firms. British Accounting Review, 43(4), 251-263. doi: 10.1016/j.bar.2011.08.004

Anthony, R., \& Govindarajan, V. (2007). Management Control Systems. New York, NY: McGraw-Hill/Irwin.

Atkinson, A. A., Balakrishnan, R., Booth, P., Cote, M. J., Groot, T., Malmi, T., Roberts, H., Uliana, E., \& Wu, A. (1997). New directions in management accounting research. Journal of Management Accounting Research, 9, 79-108.

Bisbe, J., \& Malagueño, R. (2012). Using strategic performance measurement systems for strategy formulation: Does it work in dynamic environments? Management Accounting Research, 23(4), 296-311. http://dx.doi.org/10.1016/j.mar.2012.05.002

Blocher, E. J., Chen, H. K., Cokins, G., \& Lin, T. W. (2005). Cost Management: a Strategic Emphasis. New York, NY: McGrawHill/Irwin.

Bourne, M., Kennerley, M., \& Franco-Santos, M. (2005). Managing through measures: A study of impact on performance. Journal of Manufacturing Technology Management, 16(4), 373-395. http://dx.doi.org/10.1108/17410380510594480

Brignall, S., \& Ballantine, J. (2004). Strategic enterprise management systems: new directions for research. 
Management Accounting Research, 15(2), 225-240. doi:10.1016/j. mar.2003.10.003

Cagwin, D., \& Bouman, M. J. (2002). The association between activity-based costing and improvement in financial performance. Management Accounting Research, 13(1), 1-39. doi: 10.1006/mare.2001.0175

Chen, C. X. (2015). Discussion of testing strategy with multiple performance measures: Evidence from a BSC at Store24. Journal of Management Accounting Research, 27(2), 67-73. doi: 10.2308/jmar-51157

Cheng, M. M., \& Humphreys, K. A. (2012). The differential improvement effects of the strategy map and scorecard perspectives on managers' strategic judgments. The Accounting Review, 87(3), 899-924. doi: 10.2308/accr-10212

Chenhall, R. H. (2003). Management control systems design within it organizational context: Findings form contingencybased research and directions for the future. Accounting, Organizations and Society, 28(2-3), 127-168.

Davis, S., \& Albright, T. (2004). An investigation of the effect of BSC implementation on financial performance. Management Accounting Research, 15(2), 135-153. doi: 10.1016/j. mar.2003.11.001

Domanović, V. (2009). Usklađena lista rezultata $i$ upravljanje zasnovano na aktivnostima u funkciji unapređenja efikasnosti preduzeća. Neobjavljena doktorska disertacija. Ekonomski fakultet Univerziteta u Beogradu, Beograd, Republika Srbija.

Domanovic, V. (2013). The effectiveness of performance measurement in terms of the contemporary business environment. Economic Horizons, 15(1), 33-46. doi: 10.5937/ ekonhor1301031D

Fahy, M. (2001). Strategic Enterprise Management Systems: Tools for the 21t Century. London, UK: The Chartered Institute of Management Accountants.

Ittner, C. D., \& Larcker, D. F. (1998). Are nonfinancial measures leading indicators of financial performance? An analysis of customer satisfaction. Journal of Accounting Research, 36(3), 1-35. doi: $10.2307 / 2491304$

Ittner, C., Larcker, D. F., \& Randall, T. (2003). Performance implications of strategic performance measurement in financial services firms. Accounting, Organizations and Society, 28(7-8), 715-741. doi: 10.1016/S0361-3682(03)00033-3

Kaličanin, Đ., \& Knežević, V. (2013). Activity-based costing as an information basis for an efficient strategic management process. Economic Annals, 58(197), 95-119. doi: 10.2298/ EKA1397095K
Kaplan, R. S., \& Norton, D. (1992). The BSC - measures that drive performance. Harvard Business Review, 70(1), 71-79.

Kaplan, R., \& Norton, D. (2001). The Strategy Focused Organization - How BSC Companies Thrive in the New Business Environment. Boston, USA: Harvard Business School Press.

Kennedy, T., \& Affleck-Graves, J. (2001). The impact of activitybased costing techniques on firm performance. Journal of Management Accounting Research, 13(1), 19-45. doi: http:// dx.doi.org/10.2308/jmar.2001.13.1.19

Lawson, R., Stratton, W., \& Hatch, T. (2004). Automating the BSC. CMA Management, 77(9), 39-43.

Maiga, S. A., \& Jacobs, F. A. (2003). BSC, activity-based costing and company performance: An empirical analysis. Journal of Managerial Issues, 15(3), 283-301.

Maiga, A. S, Nilsson, A., \& Jacobs, F. A. (2014). Assessing the interaction effect of cost control systems and information technology integration on manufacturing plant financial performance. The British Accounting Review, 46(1), 77-90. http://dx.doi.org/10.1016/j.bar.2013.10.001

Malina, M. A., Selto, F. H. (2001). Communicating and controlling strategy: An empirical study of the effectiveness of the BSC. Journal of Management Accounting Research, 13(1), 47-90. doi: http://dx.doi.org/10.2308/jmar.2001.13.1.47

Micheli, P., Mura, M., \& Agliati, M. (2011). Exploring the roles of performance measurement systems in strategy implementation: The case of a highly diversified group of firms. International Journal of Operations $\mathcal{E}$ Production Management, 31(10), 1115-1139. http://dx.doi. org/10.1108/01443571111172453

Mohamed, A. A., \& Jones, T. (2014). Relationship between strategic management accounting techniques and profitability - A proposed model. Measuring Business Excellence, 18(3), 1-22. http://dx.doi.org/10.1108/MBE-04-20130023

Niven, R. (2002). BSC Step by Step: Maximizing Performance and Maintaining Results. John Wiley \& Sons, Inc.

Norton, D. (1999). SAP Strategic Enterprise Management: Translating Strategy into Action: The BSC. SAP AG: SEM Product Management.

Otley, D. (1999). Performance management: A framework for management control systems research. Management Accounting Research, 10(4),363-382. doi:10.1006/mare.1999.0115

Odar, M., Kavčič, M., \& Jerman, M. (2012). Performance measurement systems: Empirical evidence from Slovenia. Economic Research, 25(2), 445-464. doi: 
10.1080/1331677X.2012.11517517

Shields, M. D. (1995). An empirical analysis of firms' implementation experiences with activity-based costing. Journal of Management Accounting Research, 7, 148-166.

Shields, D. M., \& McEwen, M. A. (1996). Implementing activity-based costing systems successfully. Journal of Cost Management, Winter, 15-22.

Stojanović Aleksić, V. (2008). Promena organizacione kulture kao jedna od ključnih pretpostavki uspešnog sprovođenja organizacionih promena u procesu tranzicije. U: I. Rosić i V. Leković, (Ur.), Institucionalne promene kao determinanta privrednog razvoja Srbije (str. 150-159). Kragujevac, Republika
Srbija: Ekonomski fakultet Univerziteta u Kragujevcu.

Swamy, R. (2002). Strategic performance measurement in the new millennium. CMA Management, 76(3), 44-47.

Tayler, W. B. (2010). The BSC as a strategy-evaluation tool: The fffects of implementation involvement and a causal-chain focus. The Accounting Review, 85(3), 1095-1117. doi: 10.2308/ accr.2010.85.3.1095

Todorovic, M., Kalicanin, Dj., \& Nojkovic, A. (2015). Practices of performance measurement in companies in the Republic of Serbia. Economic Horizons, 17(1), 45-58. doi: 10.5937/ ekonhor1501045T

\section{Received on $5^{\text {th }}$ June 2016, after two revisions, accepted for publication on $22^{\text {nd }}$ August 2016. \\ Published online on $26^{\text {th }}$ August 2016.}

Violeta Domanovic is an Associate Professor at the Faculty of Economics, University of Kragujevac. She received her $\mathrm{PhD}$ degree, at the Faculty of Economics, University of Belgrade, in the field of business economics. Key areas of her scientific interests include performance measurement and management and cost management. 


\title{
EFEKTI INTEGRISANE PRIMENE USKLAĐENE LISTE REZULTATA I UPRAVLJANJA ZASNOVANOG NA AKTIVNOSTIMA NA STRATEGIJU I EFIKASNOST PREDUZEĆA
}

\author{
Violeta Domanović* \\ Ekonomski fakultet Univerziteta u Kragujevcu
}

\begin{abstract}
Nedostaci individualne primene pojedinih menadžerskih inovacija u domenu upravljačkog računovodstva i strategijskog menadžmenta u savremenom poslovnom okruženju uslovili su neminovnost istraživanja komplementarne i integrisane primene menadžerskih inovacija. Cilj istraživanja u radu je da se pokaže kako komplementarna primena Usklađene liste rezultata i Upravljanja zasnovanog na aktivnostima u procesu upravljanja strategijom i efikasnošću preduzeća eliminiše nedostatke individualne primene istih. U radu su precizirani efekti primene Usklađene liste rezultata i Upravljanja zasnovanog na aktivnostima na strategiju preduzeća, posebno apostrofirajući ulogu informaciono-komunikacionih tehnologija u procesu njihove primene, i prezentirani su rezultati empirijskih istraživanja korelacije Usklađene liste rezultata i Upravljanja zasnovanog na aktivnostima na strategiju i efikasnost preduzeća. Uprkos mogućim problemima i ograničenjima, adekvatno sinergijsko korišćenje odnosnih menadžerskih inovacija omogućava bolju implementaciju definisane strategije i unapređenje efikasnosti preduzeća u dugom roku.
\end{abstract}

Ključne reči: Usklađena lista rezultata, Upravljanje zasnovano na aktivnostima, strategija, informacionokomunikacione tehnologije, efikasnost preduzeća

JEL Classification: M10, M21, M41

\section{UVOD}

Sistemi upravljanja performansama podrazumevaju različite organizacione aktivnosti koje menadžeri primenjuju kako bi pažnju zaposlenih usmerili na implementaciju strategije (Otley, 1999). Sistemi merenja

\footnotetext{
* Korespondencija: V. Domanović, Ekonomski fakultet Univerziteta u Kragujevcu, Đ. Pucara 3, 34000 Kragujevac, Republika Srbija; e-mail: vterzic@kg.ac.rs
}

performansi omogućavaju menadžerima da planiraju i koordiniraju aktivnosti zaposlenih, obezbeđujući tačan i pravovremen feedforward i feedback o tome kako rade i ohrabruju korektivno ponašanje kada je to neophodno (Anthony \& Govindarajan, 2007). Definisanje i implementacija strategije značajno se komplikuje u situaciji kada preduzeće nastoji da ostvari troškovnu efikasnost, s jedne strane, a da kupcima ponudi proizvode i usluge visokog kvaliteta, $\mathrm{u}$ pravo vreme i sa pouzdanom isporukom, s druge 
strane (Chenhall, 2003). U savremenom poslovnom okruženju, preduzeća usvajaju strategijske sisteme merenja performansi koji omogućavaju formulisanje i uspešnu implementaciju definisanih strategija. J. Bisbe i R. Malagueño (2012, 296-311) ispitivali su kako strategijski sistemi merenja performansi utiču na performanse i to preko definisanja strategijskih pitanja i strategijskih odluka koje proističu iz procesa (re)formulisanja strategija. J. Bisbe i R. Malagueño $(2012,309)$ ističu da postoji „veza između strategijskih sistema merenja performansi i performansi preduzeća ukoliko je dinamizam okruženja mali, ali ne i kada je nivo dinamizma visok".

Informaciono-komunikacione tehnologije predstavljaju značajan faktor $u$ procesu primene strategijskih sistema merenja performansi. Uvođenje i primena novih sistema upravljanja i informacionih sistema postalo je od suštinskog značaja za opstanak preduzeća koje nastoji da izađe u susret izazovima na globalnom tržištu. Novi sistemi merenja i upravljanja razvijeni su izolovano od drugih inicijativa i sistema, što rezultira ponavljanjem, raskorakom i neadekvatnom komunikacijom. Usled nedostatka integracionog modela, ove inicijative nisu uspele da obezbede sve obećane koristi. Integracija informacija je esencijalna kako bi se resursi preduzeća optimalno koristili. Integracija modela upravljanja troškovima i modela upravljanja performansama obezbeđuje bolju informacionu osnovu za donošenje poslovnih odluka.

Predmet istraživanja u radu je sinergijsko korišćenje strategijskih sistema merenja performansi, kao što su Usklađena lista rezultata i Upravljanje zasnovano na aktivnostima, kao menadžerskih inovacija $u$ savremenom poslovnom okruženju.

Osnovni cilj je pokazati da manjkavosti elaboriranih menadžerskih inovacija mogu biti otklonjene njihovom komplementarnom $\mathrm{i}$ integrisanom primenom.

Polazeći od defisanog predmeta i cilja istraživanja, osnovna naučna hipoteza rada je da integrisana primena Usklađene liste rezultata i Upravljanja zasnovanog na aktivnostima, uz adekvatnu software podršku, značajno doprinosi efikasnijoj implementaciji definisane strategije i efikasnosti preduzeća.
Da bi se testirala polazna hipoteza, primenjena je kvalitativna metodologija. Metodom sinteze i indukcije, i na osnovu empirijskih istraživanja različith autora $\mathrm{u}$ vezi sa korelacijom Usklađene liste rezultata i Upravljanja zasnovanog na aktivnostima, izvršeno je sintetizovanje različitih stavova, na osnovu kojih su izvedeni generalni zaključci o uticaju Usklađene liste rezultata i Upravljanja zasnovanog na aktivnostima na strategiju i efikasnost preduzeća.

U tom smislu, u radu se, najpre, govori o uticaju Usklađene liste rezultata i Upravljanja zasnovanog na aktivnostima na strategiju preduzeća. Zatim, elaborira se značaj informaciono-komunikacionih tehnologija $u$ procesu primene Usklađene liste rezultata i Upravljanja zasnovanog na aktivnostima i na kraju daju se rezultati empirijskih istraživanja korelacije Usklađene liste rezultata i Upravljanja zasnovanog na aktivnostima, i efikasnosti preduzeća. Konačno, izvedeni su odgovarajući zaključci i zauzet stav o validnosti polazne hipoteze, čime je $\mathrm{u}$ metodološkom pogledu, ostvarena veza između predmeta i cilja istraživanja. $U$ nastavku zaključnih razmatranja istaknute su teorijske i praktične implikacije istraživanja, identifikovana percipirana ograničenja i predložen pravac budućih istraživanja.

\section{UTICAJ USKLAĐENE LISTE REZULTATA I UPRAVLJANJA ZASNOVANOG NA AKTIVNOSTIMA NA STRATEGIJU PREDUZEĆA}

Strategija je značajna determinanta poslovnog uspeha preduzeća. Problem se, međutim, ne javlja u procesu formulisanja i razvijanja, već u fazi implementacije strategije. Usklađena lista rezultata (Balanced Scorecard - BSC) opisuje strategiju, raščlanjava je na pojedine delove preko zadataka i merila poslovnog uspeha iz četiri perspektive - finansija, kupaca, internih poslovnih procesa, učenja i rasta. BSC se kreira razumevanjem i prevođenjem strategije na ciljeve, merila, zadatke i inicijative za realizaciju definisanih ciljeva i zadataka iz svih perspektiva. Kroz proces razvijanja BSC, izvršni tim mora odrediti da svetska klasa podrazumeva proizvodnju sa nultim defektom proizvoda i usluga. Svi zaposleni sada mogu svoju energiju i svakodnevne 
aktivnosti fokusirati na jasan cilj - proizvodi i usluge bez defekata, pre nego na razmišljanje o tome šta svetska klasa uistinu predstavlja. Primenom BSC-a kao modela za prevođenje strategije, preduzeća kreiraju novi jezik merenja koji služi za usmeravanje akcija svih zaposlenih ka ispunjenju definisanog pravca.

Ključni atribut definisanja strategije je sprovođenje drugačijih aktivnosti od svojih rivala. Izborom različitih srodnih aktivnosti, preduzeće ima mogućnosti da kreira jedinstvene predloge vrednosti za kupce i na taj način da se diferencira u odnosu na svoje konkurente. Ove aktivnosti se moraju izraziti u BSC-u i treba da se uporede sa strategijom preduzeća. Drugim rečima, ukoliko preduzeće želi da se diferencira na taj način što izgrađuje odnos prisnosti sa kupcima, tada BSC treba da odražava ovaj strategijski pravac. Nakon toga, treba definisati različita merila performansi iz različitih perspektiva, koje zajedno posmatrano utiču na sprovođenje strategije. Merila koja se odnose na usluge ciljnim kupcima treba istaći $\mathrm{u}$ perspektivi kupci, povezati sa metrikom $\mathrm{u}$ internoj perspektivi i perspektivi učenja i rasta. Pretpostavlja se da ovaj lanac povezanih merila, u kojem se ogledaju izabrane aktivnosti preduzeća, utiče na rast prihoda i profita u finansijskoj perspektivi. Još jednom, BSC je instrumentarijum za opisivanje i artikulisanje aktivnosti koje posmatrano preduzeće izdvajaju od konkurenata.

BSC i strategija idu ruku pod ruku. Bez obzira na to da li se BSC koristi za ocenu efikasnosti preduzeća ili ne, ona predstavlja moćan model za usmeravanje menadžera $\mathrm{ka}$ ispunjenju strategijskih ciljeva. U skladu sa ovim, R. Kaplan i D. Norton (2001, 42-43; 139) su razvili koncept Mape strategije, koja koristi BSC kako bi detaljno opisala strategiju pomoću uzročnoposledičnih dijagrama. Jednostavna mapa strategija data je na Slici 1. Mapa strategije povezuje sve četiri perspektive BSC-a, pokazujući kako merljivi ciljevi $\mathrm{u}$ svakoj perspektivi doprinose performansama u sledećoj perspektivi. Mapa strategije započinje sa perspektivom učenja i inovacije, koja uključuje ciljeve - kompetentnost zaposlenih, svest o strategiji i tehnološku infrastrukturu. Ovi ciljevi direktno doprinose perspektivi internih poslovnih procesa, $u$ kojima zaposleni primenjuju svoje kompetentnosti i razvijaju svest o strategiji i koriste tehnološku infrastrukturu. Na sličan način, ciljevi iz perspektive svakodnevnih poslovnih aktivnosti komplementarni su sa ciljevima iz perspektive kupaca. Ciljevi iz perspektive kupaca komplementarni su sa ciljevima iz finansijske perspektive. Kako svako preduzeće ima različitu BSC, tako ima i različitu Mapu strategije. Mapa strategije je detaljan pregled o tome kako preduzeće ostvaruje svoje strategijske ciljeve, pokazujući interakcije između perspektiva u BSC-u (Kaplan \& Norton, 2001).

Mapa strategije podržava ideju da su finansijske performanse i vrednost za akcionare krajnji ciljevi za mnoge aplikacije BSC-a. Sve ostale perspektive doprinose direktno konačnim finansijskim ciljevima. Zapravo, nefinansijska merila u ostalim perspektivama su dobri prognozeri budućih finansijskih performansi (Ittner \& Larcker, 1998, 1-35). Mapa strategije ističe da se BSC, opisujući detaljnije strategiju preduzeća, može iskoristiti kao instrument za razvijanje strategije i procenu dinamike realizacije definisane strategije.

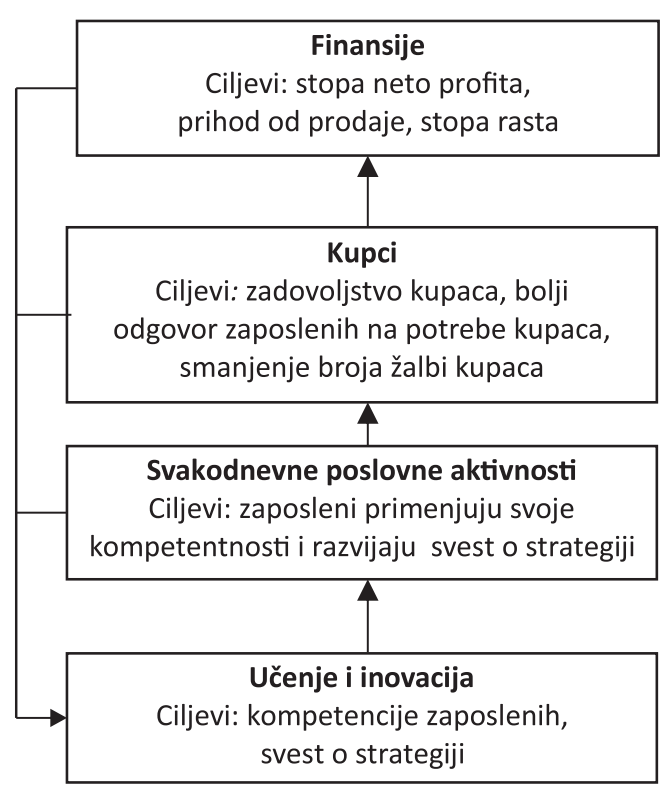

Slika 1 Mapa strategije prema Usklađenoj listi rezultata

Izvor: Autor, na osnovu: Blocher, Chen, Cokins \& Lin, 2005, 742 
Kao informaciona podrška BSC-u, javlja se obračun troškova po aktivnostima (Activity-Based Costing BSC). Koncept obračuna troškova po aktivnostima i Upravljanje zasnovano na aktivnostima (ActivityBased Management - ABM) olakšavaju strategijsko upravljanje troškovima. Ovaj koncept ne pokazuje samo kako aktivnosti troše resurse i kako proizvodi ili kupci izazivaju aktivnosti, već, takođe, alocira troškove na proizvode i aktivnosti prema resursima koje troše. $\mathrm{ABC}$ opisuje preduzeće kao seriju aktivnosti usmerenih ka zadovoljenju potreba kupaca. $\mathrm{ABC}$ pruža menadžerima informacije za upravljanje aktivnostima u cilju poboljšanja konkurentnosti i dostizanja strategijskih ciljeva. ABC i BSC su dva moderna i komplementarna koncepta (Kaličanin \& Knežević, $2013,114)$. Đ. Kaličanin i V. Knežević $(2013,114)$ ističu da između ovih koncepata postoji direktan odnos ukoliko se u BSC uključe sve relevantne informacije koje se odnose na konkurentsku prednost preduzeća. Ovo znači da će se uključiti informacije dobijene iz ABC-a. Logično je da se najveći broj ciljeva i merila definiše upravo iz finansijske perspektive. Uobičajeni ciljevi u ovoj perspektivi su rast prihoda, povećanje produktivnosti i niži troškovi. S obzirom na to da se definišu u agregatnoj formi, potrebno je formulisati ciljeve i merila iz perspektive internih poslovnih procesa, gde se upravo i kreira vrednost. S obzirom na to da se interni poslovni procesi sastoje od aktivnosti, ABC predstavlja neophodnu podršku za analizu troškova i efekata tih aktivnosti.

Strategijski izbori određuju aktivnosti. Uspešna preduzeća svoje resurse troše na aktivnosti koje vode ka najvećoj strategijskoj koristi. Preko merenja troškova aktivnosti i identifikacije aktivnosti u proizvodnji proizvoda i pružanja usluga, $\mathrm{ABC}$ i $\mathrm{ABM}$ pomažu menadžerima da razumeju odnos između strategije preduzeća i aktivnosti i resursa koji su neophodni za implementaciju definisane strategije.

Za preduzeća koja slede strategiju vođstva u troškovima u cilju sticanja konkurentske prednosti, $A B C$ i ABM od kritičnog su značaja zato što identifikuju ključne aktivnosti, uzročnike troškova i načine poboljšanja procesa u cilju redukcije troškova.

Ovi koncepti su, takođe, od pomoći i menadžerima koji slede strategiju diferenciranja tako što identifikuju mogućnosti povećanja vrednosti, razvijaju strategiju kupaca; podržavaju strategiju liderstva u tehnologiji i ustanovljavaju strategiju određivanja cena identifikovanjem i analiziranjem ključnih aktivnosti, procesa, izazivača troškova i metoda poboljšanja.

Generalno, $\mathrm{ABC}$ i $\mathrm{ABM}$ daju odgovore na pitanja iz domena strategijskog upravljanja troškovima, olakšavaju identifikaciju najbolje strategije, i od pomoći su pri realizaciji strategijskih ciljeva (Blocher et al, 2005, 162):

\begin{abstract}
„Kako se strukture troškova i profiti upoređuju sa konkurentskim? Kako se prelaz od obračuna troškova na osnovu obima na obračun troškova po osnovu aktivnosti odražava na određivanje cena, dizajn proizvoda, dizajn procesa, tehnologiju proizvodnje i odluke o proizvodnoj liniji? Kakvi su efekti troškova na različite proizvode kada preduzeće usvaja novu strategiju, na primer, promena od masovne proizvodnje standardizovanih proizvoda prema maloserijskoj proizvodnji proizvoda po ukusima kupaca? Da li je preduzeće usvojilo najrentabilniji sistem distribucije za svoje proizvode? Kako će promene u aktivnostima i komponentama uticati na dobavljače i kupce $\mathrm{u}$ lancu vrednosti? Kako će promene u poslovnim procesima uticati na krajnji rezultat? Koje su potencijalne uštede $\mathrm{u}$ troškovima ukoliko preduzeće primenjuje $\mathrm{ABM}$ za identifikaciju i eliminisanje aktivnosti koje dodaju malo vrednosti, a u cilju realizacije strategije niskih troškova? Kako ABC i ABM mogu biti od pomoći preduzeću pri sprovođenju promena u cilju ostvarenja konkurentske strategije dobrih performansi i kratkog vodećeg vremena u isporuci svojih proizvoda?"
\end{abstract}

Sistemi upravljanja performansama treba da su u skladu sa strategijom. Preduzeća koja biraju strategiju vođstva u troškovima opredeljuju se za sisteme upravljanja performansama koji se baziraju na „konzervativnim organizacionim kulturama, centralizovanim organizacionim strukturama, specijalizovanim i formalizovanim radnim procedurama, jednostavnim mehanizmima koordinacije, formalnom, finansijski zasnovanom strategijskom planiranju, kratkoročnom budžetiranju" (Stojanović Aleksić, 2008, 150-159; Adler, 2011, 260). Preduzeća koja usvajaju strategiju diferenciranja dizajniraju sisteme upravljanja performansama koji se baziraju na „preduzetničkim organizacionim kulturama, decentralizovanim 
organizacionim strukturama, nestandardnim radnim procedurama, kompleksnim sistemima koordinacije, kvalitativno zasnovanom strategijskom planiranju, dugoročnom sistemu budžetiranja" (Adler, 2011, 260).

Polazeći od misije, vizije, vrednosti i strategije preduzeća, izgrađuje se BSC na najvišem nivou korporativni BSC model. Korporativni BSC sadrži serije povezanih zadataka i merila i na osnovu uzročnoposledičnih veza govori o strategiji. Fokusirajući se na korporativni BSC, razvijaju se Usklađene liste rezultata na nižim nivoima u preduzeću. Ovo omogućava top menadžerima da imaju uvid u kojoj meri menadžeri na nižim nivoima i pojedinci zaposleni u preduzeću doprinose ostvarenju korporativnih ciljeva. Inicijative u svim Usklađenim listama rezultata iziskuju alokaciju resursa, koje se kvantifikuju i koriste za formiranje osnove predloga budžeta (Niven, 2002, 229).

Sa BSC-om, kao vodičem, menadžeri zahtevaju povratnu spregu i učešće zaposlenih pri izradi budžeta. BSC uvodi novi model upravljanja koji u centar organizacionog univerzuma stavlja strategiju, a ne finansijske kontrole. Finansijska kontrola bi bila pogodna za organizacije koje se bave smanjenjem rashoda, postavljanjem ciljnih vrednosti, kontrolom ostvarenih performansi sa ciljnim vrednostima i preduzimanjem mera da se poboljšaju performanse neefikasnog menadžment tima (Micheli, Mura \& Agliati, 2011, 1117). Fleksibilno budžetiranje se u sistemima upravljanja troškovima smatra sredstvom kontrole opštih troškova. Nasuprot tome, sistem strategijske kontrole, kao što je sistem BSC, veći fokus stavlja na ključne faktore uspeha i kroz primenu šireg seta finansijskih i nefinansijskih indikatora, strategijski planovi bi se efikasnije mogli prevesti u akciju (Micheli et al, 2011, 1117).

\section{INFORMACIONO-KOMUNIKACIONE TEHNOLOGIJE U FUNKCIJI IMPLEMENTACIJE BSC-a I ABM-a}

Merenje efikasnosti preduzeća je proces koji je evoluirao onako kako su preduzeća menjala svoje poslovne procese $\mathrm{u}$ skladu sa zahtevima savremenog poslovnog okruženja. U periodu 1960-1980, preduzeća su svoje performanse ocenjivala skoro isključivo na osnovu finansijskih merila. Tokom 1980-ih, preduzeća u Sjedinjenim Američkim Državama povećala su broj analiziranih merila, mada se većina oslanjala na kratkoročna merila koja su bila kratkovida i manje konkurentska u odnosu na merila korišćena u preduzećima Japana i Evrope. Tokom 1990-ih, uveden je BSC model, koja se smatrala glavnom inovacijom $u$ merenju performansi. BSC model je „kvantifikovao i inkorporirao nefinansijske podatke $\mathrm{u}$ izveštajni sistem merenja čineći ih tako konzistentnim i značajnim" (Swamy, 2002, 44).

Od kraja 1990-ih, preduzeća su proširila svoje lance poslova, s obzirom da je internet dobio nezamenljivu ulogu u poslovnom svetu. Otuda, Web analitika je dobila na značaju u procesu merenja i ocene poslovnih performansi. Web analitika je analiza podataka sa websajta kako bi se odredio uspeh web-sajta i razumelo ponašanje kupaca. Sa ovim informacijama, preduzeće može skupiti podatke o preferencijama kupaca, povratnoj sprezi i demografske podatke, koji bi bili od pomoći pri generiranju većih prihoda i redukciji troškova (Swamy, 2002, 44). Preduzeće u savremenom poslovnom okruženju mora napraviti „pravu kombinaciju tradicionalnih merila performansi, da ih podrži Web analitikom, i poveže sa vizijom i strategijom, kako bi se proizveo holistički pogled na organizaciju". U XXI-om veku, BSC model sadrži još dve nove perspektive, $\mathrm{i}$ to elektronsko poslovanje $\mathrm{i}$ perspektivu korisnika.

Perspektiva elektronskog poslovanja povezuje $u$ tradicionalnom BSC modelu zadatke iz perspektive kupaca i finansija, i fokusira se na povećane profite i tržišno učešće. Ova perspektiva uključuje finansijska i tržišna merila, na osnovu „interakcije korisnika sa Web zasnovanim tehnologijama". Korisnci Web zasnovanih sistema mogu biti eksterni kupci, interno zaposleni, i dobavljači i partneri. Kada se razvija metrika iz elektronske perspektive, treba analizirati tipove procesa koji se postavljaju za Web zasnovane inicijative i njihovu osnovnu nameru. Perspektiva korisnika podržava internu i perspektivu učenja u tradicionalnom BSC modelu, fokusirajući se na iskustvo korisnika i performanse tehnologije. Pri izboru metrike za ovu perspektivu, treba se fokusirati na procese koji poboljšavaju efikasnost preduzeća i na 
to kako korisnici ocenjuju ove procese (Swamy, 2002, 47).

Polazeći od zahteva koje pred savremeno preduzeće nameću strategijski i operativni menadžment, a u cilju uspešne implementacije BSC i ABM, potrebno je ove sisteme upravljanja i merenja automatizovati. Ovo iz razloga ne samo ažuriranja podataka već i sastavljanja i emitovanja izveštaja. Periodično ažuriranje podataka i priprema proširenog računovodstvenog izveštaja, kao što je BSC, iziskuje značajno vreme i napor. „Rezultati istraživanja ukazuju da 70\% preduzeća koja su uvele BSC i ABM primenjuju neki tip software-a u procesu implementacije" (Lawson, Stratton \& Hatch, 2004, 40). Od ovih preduzeća, „31\% primenjuje eksterne software (off-the-shelf software), $43 \%$ primenjuje software koji su razvijeni u svojoj kući (in-house software), a 27\% preduzeća koriste i jedan i drugi software" (Lawson et $a l, 2004,40)$.

Potreba za uvođenjem software-a $\mathrm{u}$ procesu implementacije sistema BSC i ABM povećava se sa rastom veličine preduzeća. Mala preduzeća ne primenjuju software za ove sisteme (59\%) (Lawson et al, 2004, 40). Ovaj procenat se smanjuje onako kako se povećava veličina preduzeća. Isto važi i za eksterne i interne software. Procenat preduzeća koja ih primenjuju povećava se sa povećanjem veličine preduzeća. Glavna prednost primene software-a ogleda se $u$ tome što se ostvaruju uštede $u$ vremenu, koje bi inače bilo utrošeno na aktivnosti koje ne dodaju vrednost. Software ohrabruje promene $\mathrm{u}$ poslovnim procesima. Uvođenje i primena software-a, međutim, imaju svoju cenu. Cena sadrži, pored troškova implementacije i eksploatacionih troškova, i nadoknadu za pravo korišćenja (licencu). U procesu implementacije BSC i ABM preduzeće može započeti sa relativno jednostavnim sistemom. Vremenom, međutim, menadžeri postaju svesni ograničenja ovih jednostavnih, i teže uvođenju sofisticiranijih sistema. Vredno je pomenuti da su „najčešće korišćeni softwareski paketi su Hyperion's Performance Scorecard i OROS" (Lawson et al, 2004, 41).

Jedna od najpoželjnijih karakteristika sistema za implementaciju BSC i ABM jeste fleksibilnost dizajna izveštaja. Implementacija BSC i ABM je iterativan proces. Većina menadžera će osećati da imaju isuviše merila ili da nemaju pravo merilo. Činjenica da imaju mnoštvo merila ne garantuje da je izabrano pravo merilo. Vremenom, pošto prime povratnu informaciju od korisnika, menadžeri će zaključiti da su neka merila suvišna, a neka nedostaju. Fleksibilnost je značajna karakteristika $\mathrm{u}$ automatizaciji BSC. Fleksibilnost se zahteva i zbog promena u sistemima obrade podataka. Preduzeća mogu razviti Enterprise Resource Planning - ERP sisteme, instalirati kompjutere „koje mogu svi koristiti i koji mogu obavljati veoma komplikovane zadatke ili instalirati neke druge sisteme" (Lawson et al, 2004, 42-43).

\section{Dobavljači ERP sistema tvrde da nude}

„integrisano rešenje za planiranje, izvršenje i kontrolu poslovnih procesa horizontalno duž lanca vrednosti SAP R/3 (tržišni lider) integriše procese kao što su planiranje prodaje i materijala, proizvodnja, upravljanje skladištem, finansijsko i upravljačko računovodstvo i upravljanje ljudskim resursima“" (Norton, 1999, 38).

Strategijski sistemi za upravljanje preduzećem (Strategic Enterprise Management Systems - SEMs) omogućavaju formulisanje i implementaciju strategije pomoću BSC, vrednovanje strategije preko pokretača vrednosti, ali i operativni menadžment preko praćenja performansi, izrade biznis planova, konsolidacije biznis planova $\mathrm{i}$ komuniciranja sa interesnim grupama.

Strategijski sistemi za upravljanje preduzećem teže povezivanju merenja performansi i kontrole sa strategijskim zadacima, u pokušaju da se obezbedi da donošenje operativnih odluka bude potpuno fokusirano na definisanje strategijskih zadataka (Fahy, 2001, 173). Da bi se jedan sistem okvalifikovao kao SEM treba da ima sledeće atribute (Brignall \& Ballantine, 2004, 229):

„treba da se izgradi na ERP sistemu; SEMs se oslanjaju na alate skladištenja podataka, kao što su centri troškova u ABM-u; SEMs uključuju različite integrisane modele, kao što su ABM, BSC i drugi modeli poslovnog izveštavanja i analize; ovi sistemi imaju kako interni, tako i eksterni tržišni fokus i pružaju podršku u procesu donošenja strategijskih odluka".

Tržišni lider u ERP sistemima, SAP AG, nudi integrisani sistem za strategijsko upravljanje preduzećem, koji 
sadrži pet glavnih aplikacija i pridruženih alata (Brignall \& Ballantine, 2004, 229): „poslovno planiranje i simulacija, konsolidacija poslovanja, kontrola poslovnih performansi, prikupljanje poslovnih informacija i upravljanje odnosima sa interesnim grupama". Slika 2 ilustruje kako SAP-ova verzija SEM-a podržava upravljanje strategijskom promenom i integrisane procese upravljanja povezane sa strategijom, na osnovu suštinskog koncepta BSC-a.

Kao informaciona osnova BSC-a javljaju se ABC i ABM. U cilju uspešne i lakše implementacije ABM modela, potrebno je uvesti odgovarajući software. Softwareski paketi su raspoloživi, robusni i laki za upotrebu, pri čemu su podložni kontinuelnom razvoju. Takav software dizajniran je u cilju olakšanja izgradnje velikih modela visoke kompleksnosti, dok $\mathrm{u}$ isto vreme olakšava raspodelu troškova. ABM software se koristi za održavanje podataka u vezi sa kompletnim asortimanom gotovih i delimično gotovih proizvoda koji se proizvode i/ili prodaju. Takvi sistemi mogu biti u vezi sa sistemima budžetiranja i sistemima koji se koriste za izveštavanje stvarnih nasuprot budžetiranim performansama. Ovi modeli, takođe, omogućavaju utvrđivanje prodajnih cena proizvoda i donošenje drugih poslovnih odluka. $\mathrm{ABC}$ može biti povezan i sa sistemom kontrole zaliha kako bi se obezbedilo vrednovanje zaliha.

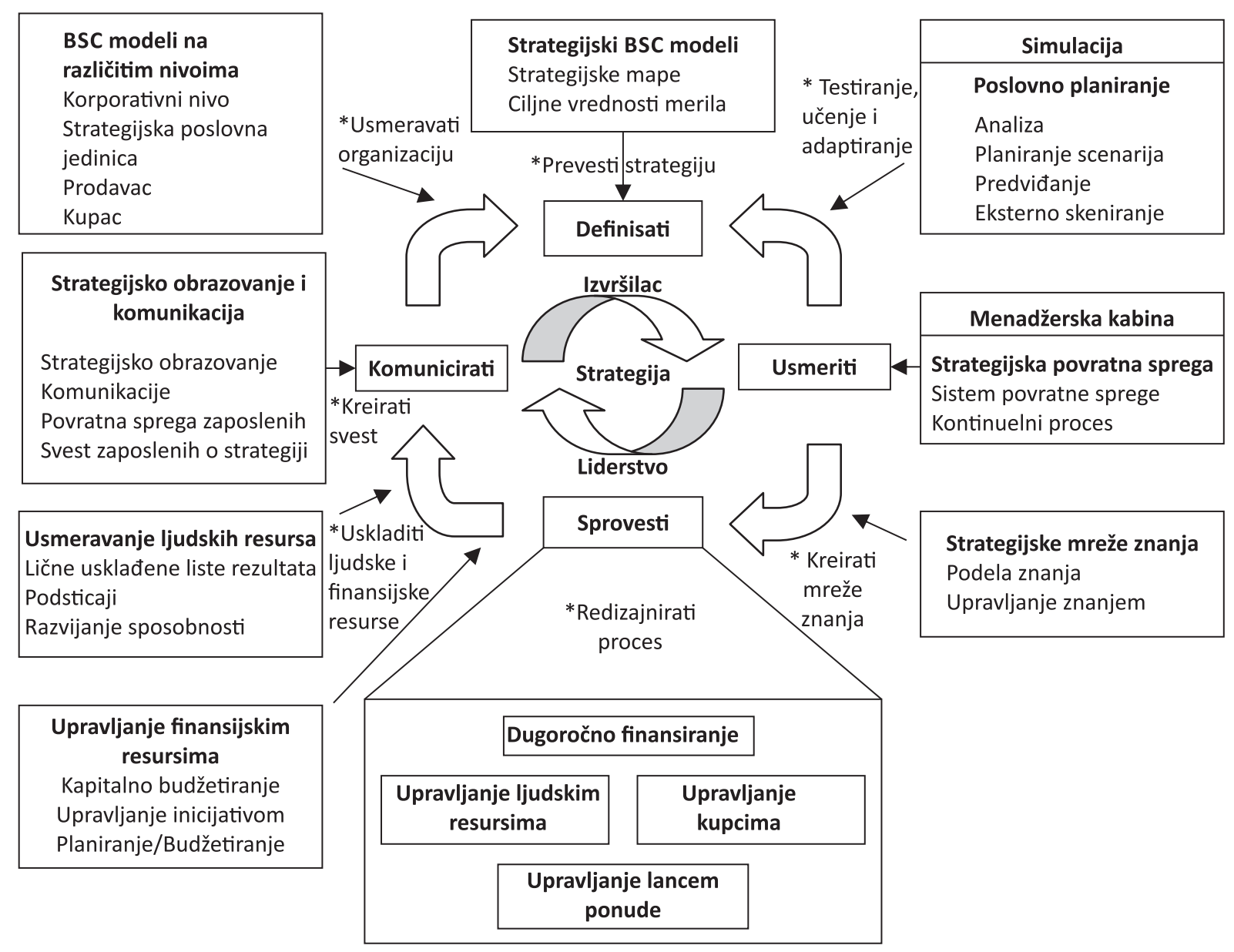

Slika 2 SAP-ovo rešenje Usklađene liste rezultata 


\section{EMPIRIJSKA ANALIZA KORELACIJE IZMEĐU BSC-A, ABM-A I EFIKASNOSTI PREDUZEĆA}

Počevši od ranih 1980-ih godina, istraživači u domenu upravljačkog računovodstva opisali su sve veću irelevantnost prakse tradicionalne kontrole i merenja performansi. Slabosti ovih praksi ogledale su se $u$ nemogućnostima povezivanja „merenja performansi sa strategijskim inicijativama preduzeća”, sa akcentom na „eksterno izveštavanje umesto na računovodstvene izveštaje korisne za interno odlučivanje”, kao i u nemogućnostima uspešnog praćenja tehnološkog progresa. Karakteristike savremenog poslovnog okruženja nametnule su potrebu uvođenja i primene alternativnih modela merenja performansi i kontrole.

BSC model je nastao kao rezultat potrebe poboljšanja funkcija upravljačkog računovodstva - planiranja, kontrole i merenja performansi. A. A. Atkinson, R. Balakrishnan, P. Booth, M. J. Cote, T. Groot, T. Malmi, H. Roberts, E. Uliana i A. Wu (1997, 79-108) izjavili su da je BSC model dobio posebno mesto i ulogu u oblasti upravljačkog računovodstva. Pa ipak, postoji malo studija o tome kako ovaj koncept utiče na finansijske performanse preduzeća ili se nedovoljno ističe da je BSC superiorniji $\mathrm{u}$ odnosu na druge sisteme merenja performansi. Primarno načelo BSC-a je da se uspeh ostvaruje prevashodno na ključnim nefinansijskim merilima, a ne na finansijskim merilima.

$\mathrm{ABC}$ i ABM promovisani su kao osnova za donošenje strategijskih odluka i za poboljšanje profitnih performansi već više od jedne decenije. $A B C$ informacije se danas široko primenjuju za procenu kontinuelnog poboljšanja i kontrolu procesnih performansi. Iako je ovaj koncept ubrzo prihvaćen, postoji raznolikost mišljenja u vezi njegove efikasnosti, korisnosti, relevantnosti i praktične primenljivosti. Uprkos činjenici da menadžeri insistiraju da sistemi upravljačkog računovodstva prolaze test troškova i koristi, još uvek ne postoji institucionalizovani empirijski dokaz o validnosti koristi ABC-a. U tu svrhu potrebni su empirijski dokazi o finansijskim posledicama implementacije ABM-a.

T. Kennedy i J. Affleck-Graves (2001) empirijski su dokazali da primena $\mathrm{ABC}-\mathrm{a}$ značajno poboljšava relativne performanse preduzeća i to posmatrano, kako prema tržišnim, tako i prema računovodstevno zasnovanim merilima. Za elaboraciju empirijske analize korelacije između BSC-a, ABM-a i finansijskih performansi poslužila je studija S. A. Maiga i F. A. Jacobs-a (2003, 283-301). Ono što je od posebnog značaja, to je uticaj integrativne primene ABM-a i BSC-a na efikasnost poslovanja preduzeća. Da bi se testirali efekti interakcije ABM-a i BSC-a, jedna varijabla se koristi za merenje ABM-a, a četiri za merenje BSC-a.

ABM merila: Da bi se došlo do željenog kvaliteta $u$ procesu implementacije $A B C-a$, treba uzeti $u$ obzir one varijable koje su u najbližoj vezi sa uspehom ovog koncepta, a to su upravo one koje se najčešće javljaju u procesu implementacije. M. D. Shields (1995, 148-166) je prvi uradio empirijsku studiju u kojoj predlaže izvesne "organizacione i tehničke faktore", koji su povezani sa $A B C$ uspehom. Ovaj autor otkrio je da je $A B C$ u značajnoj korelaciji sa nekoliko kategorija primene: merenje performansi, analiza aktivnosti, obračun troškova proizvoda i reinženjering. Osim toga, otkrio je da postoji značajna korelacija uspeha sa procentom troškova koji su obrađeni u ABC-u. Otuda su i u ovde razmatranoj studiji varijable povezane sa bazičnim okvirom M. D. Shields-a. Konkretno, prikupljani su podaci o šest $A B C$ varijabli (Maiga \& Jacobs, 2003, 288):

„(1) podrška vrha preduzeća, (2) konsenzus o zadacima, (3) veza sa konkurentskom strategijom, (4) povezanost sa inicijativom o kvalitetu, (5) verovanje i neračunovođa da je $\mathrm{ABC}$ sistem od praktične primene svim zaposlenima u organizaciji, a ne samo računovodstvenom odeljenju i (6) ocena performansi/ kompenzacija (pretpostavlja se da je u bliskoj vezi sa ABC uspehom)".

M. D. Shields i M. A. McEwen (1996, 15-22) navode sedam faktora uspeha $\mathrm{ABC}$ implementacije:

„podrška vrha preduzeća; povezanost sa konkurentskom strategijom, ističući kvalitet i sistem baš na vreme (Just-in-Time)/brzinu; povezanost sa ocenom performansi i kompenzacijom; obuka zaposlenih; neračunovodstveno vlasništvo; adekvatni resursi; i konsenzus i jasnoća ABC zadataka".

BSC merila: Polazeći od autora R. S. Kaplan-a i D. Norton-a (1992, 71-79), BSC se meri primenom nekoliko 
varijabli iz četiri bazične perspektive. Perspektiva kupaca sadrži osam varijabli: „vreme odgovora kupaca, ispitivanje zadovoljstva kupaca, broj žalbi kupaca, isporuka na vreme, vreme koje prođe od narudžbine kupaca do isporuke gotovih proizvoda, broj vraćenih isporuka zbog lošeg kvaliteta, troškovi popravke, garancije i tržišno učešće". Perspektiva internih poslovnih procesa uključila je šest varijabli: „proizvodno vodeće vreme, racio dobrih output-a i ukupnih output-a, odstupanje efikasnosti radne snage, odstupanje efikasnosti materijala, stopa otpadaka materijala, procenat defektnih isporučenih proizvoda". Perspektiva učenja i rasta podrazumevala je tri varijable: „broj novih patenata, vreme neophodno za lansiranje novog proizvoda, broj lansiranih novih proizvoda". Iz finansijske perspektive definisane su tri varijable: "prinos na investicije, rast prihoda od prodaje, poslovni dobitak". Performanse preduzeća su ocenjene prema zavisnim varijablama: „kvalitet proizvoda, zadovoljstvo kupaca, i stopa neto profita".

U nameri da se dobiju validniji rezultati, neophodno je uključiti i neku kontrolnu varijablu, kao što je veličina preduzeća. Neki autori smatraju da mala preduzeća često izbegavaju inovacije ne zbog nedostatka resursa već i zbog percipiranog nedostatka resursa. S druge strane, velika preduzeća imaju više kapitalnih resursa i profesionalnu ekspertizu upravljanja. Istraživanje o inovativnosti u zavisnosti od veličine preduzeća donelo je kombinovane rezultate. S. A. Maiga i F. A. Jacobs $(2003,289)$ ističu da:

„ne postoji statistički značajan odnos između veličine preduzeća i odluke o usvajanju ABC-a i ABM-a; da nema povezanosti između veličine preduzeća i broja promena u upravljačkom računovodstvu, ali da postoji pozitivna korelacija između veličine preduzeća i elaboriranih inovacija upravljanja".

Da bi se dokazalo da su ABM i BSC značajno povezani, primenjivana je hijerarhijska regresiona analiza. Inicijalno su izvedeni sledeći regresioni modeli za testiranje ovih predloga (Maiga \& Jacobs, 2003, 291):

„Organizacione performanse (zadovoljstvo kupaca, kvalitet proizvoda i stopa neto profita) $=\alpha_{0}+\beta_{1}$ Veličina $+\beta_{1}$ Kupac $+\beta_{2}$ Interni poslovni procesi $+\beta_{3}$ Učenje $+\beta_{4}$ Finansije $+\beta_{5}$ BSC $+\varepsilon . "$
„Organizacione performanse (zadovoljstvo kupaca, kvalitet proizvoda i stopa neto profita) $=\alpha_{0}+\alpha_{1}$ Veličina $+\beta_{1}$ Kupac $+\beta_{2}$ Interni poslovni procesi $+\beta_{3}$ Učenje $+\beta_{4}$ Finansije $+\beta_{5}$ BSC $+\beta_{6}$ KUPAC ${ }^{*}$ BSC $+\beta_{7}$ Interni poslovni procesi* $\mathrm{BSC}+\beta_{8}$ Učenje*BSC $+\beta_{9}$ Finansije ${ }^{*} \mathrm{BSC}+\varepsilon$, gde se veličina preduzeća meri brojem zaposlenih radnika, BSC - stepen implementacije obračuna troškova po aktivnostima, $\varepsilon$ - slučajna greška."

Rezultati studije ukazuju da je svaka od četiri perspektive $\mathrm{u}$ BSC-u $\mathrm{u}$ interakciji sa ABC-om kako bi uticala na performanse. Pa ipak, nije ustanovljena značajna pozitivna interakcija između internih poslovnih procesa u BSC-u i ABC-u kako bi se uticalo na neto rentabilnost preduzeća. Teorijski i empirijski posmatrano, moguće je podržati shvatanje da BSC i ABM mogu imati komplementarni ili sinergijski efekat na performanse preduzeća.

Još jedno istraživanje vredno pomena u kontekstu korelacije posebno ABC-a i ABM-a i finansijskih performansi preduzeća je istraživanje $\mathrm{D}$. Cagwin-a i M. J. Bouwman-a (2002, 1-39). Uticaj ABC/ABM na finansijske performanse ispitivan je pomoću sledećeg modela (Cagwin \& Bouwman, 2002, 5):

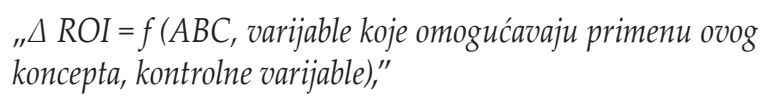

gde je " $\Delta$ ROI promena prinosa na ulaganje izmerenog tokom proteklih tri do pet godina";

„varijable koje omogućavaju primenu koncepta obračuna troškova po aktivnostima: informacionokomunikacione tehnologije, kompleksnost/ diversifikovanost, značaj troškova, intrakompanijske transakcije, neiskorišćen kapacitet i konkurencija";

kontrolne varijable uključuju veličinu i tip preduzeća.

Rezultati studije (Cagwin \& Bouwman, 2002, 2-3) pokazuju da se dobijaju pozitivne sinergije od komplementarne primene $\mathrm{ABC}$ sa drugim inicijativama upravljanja, mada nije eksplicitno ustanovljeno sa kojom inicijativom konkretno $\mathrm{ABC}$ donosi najveće koristi po preduzeće. Kada se $\mathrm{ABC}$ koristi komplementarno sa ovim drugim inicijativama, tada preduzeća ostvaruju neto poboljšanje $u$ finansijskim performansama veće nego $u$ slučaju primene ovih 
inicijativa bez $\mathrm{ABC}-\mathrm{a}$. Vođene su diskusije, ali nije i demonstrirano, da je suma koristi od primene $A B C$ veća od troškova koji nastaju u vezi sa tim. Osim toga, vidljive su pozitivne asocijacije između $A B C$ i poboljšanja $u$ prinosu na ulaganja ukoliko se $A B C$ primenjuje $\mathrm{u}$ diverzifikovanim firmama, $\mathrm{u}$ okruženju gde je strategija niskih troškova od velikog značaja.

S. Davis i T. Albright (2004, 135-153) su istraživali efekat implementacije posebno BSC-a na finansijske performanse. Svrha ovog istraživanja bila je da se ispita uticaj BSC-a na finansijske performanse. BSC model je dobio sve veću popularnost kao instrument upravljanja koji povezuje akcije zaposlenih i ciljeve sa korporativnom strategijom, od kad je uveden, 1992. Ovi autori su posmatrali uticaj primene ovog koncepta na finansijske performanse banke. Studija o kojoj je ovde reč se unekoliko razlikuje od prethodnih studija (Davis \& Albright, 2004, 136):

„iako je ranije istraživanje ispitivalo odnose između nefinansijskih merila i performansi, nije se tragalo za uspostavljanjem veze između implementacije BSC-a i boljih finansijskih performansi; studija o kojoj je reč koristi kvazi-eksperimentalni pristup u cilju ispitavanja efekata primene BSC-a na organizacione performanse; istraživanje polazi od stvarnih podataka o finansijskim performansama za individualne poslovne jedinice $\mathrm{u}$ organizaciji i primenjuje longitudinalni pristup kako bi se odredilo da li do promena u finansijskim performansama dolazi nakon implementacije sistema BSC-a".

M. A. Malina i F. H. Selto (2001) istraživali su efektivnost BSC-a u komuniciranju strategijskih ciljeva i zadataka. Nalaze da postoji indirektan odnos između uloge BSC-a kao instrumenta menadžment kontrole i boljih performansi, posmatrano po merilima performansi iz perspektiva BSC-a. BSC dovodi do veće efikasnosti i profitabilnosti. Nasuprot tome, C. Ittner, D. F. Larcker i T. Randall (2003) zaključuju da postoji negativna korelacija između primene BSC-a i stope prinosa na aktivu kao finansijske performanse.

W. B. Tayler (2010) je pomoću eksperimenta ocenio efekte implementacije BSC-a na ocenu strategije preduzeća. Rezultati istraživanja pokazuju da menadžeri koji su uključeni u izbor merila performansi i uzročno-posledični odnosi u BSC-u mogu ublažiti optimističke ocene strategija. Kada menadžeri koriste podatke iz BSC-a za ocenu uspeha jedne strategijske inicijative $u$ čijem izboru su učestvovali, ocenjuju je kao uspešniju u odnosu na menadžere koji nisu bili uključeni u proces izbora inicijative. W. B. Tayler (2010) ističe značaj uzročno-posledičnih odnosa u BSC-u. Uzročno-posledični odnosi sami za sebe nisu dovoljan razlog da bi menadžeri bili motivisani u procesu ocene strategije. W. B. Tayler $(2010,1112)$ ističe da „uključivanje menadžera u izboru merila performansi $\mathrm{u}$ kombinaciji sa fokusom na lanac uzroka i posledica dovodi do bolje ocene strategije preduzeća".

M. M. Cheng i H. A. Humphreys $(2012,899)$ ispitivali su efekat ključnih elemenata BSC-a na sposobnost menadžera da interpretiraju strategijsku relevantnost eksternih informacija i primenu tih informacija za ocenu adekvatnosti strategije preduzeća. Autori nalaze da prezentiranje strategijskih zadataka kao mape strategije, $u$ integralnoj vezi sa eksplicitnim opisom uzročnih povezanosti $\mathrm{u}$ mapi strategije, povećava relevantnost menadžerskih informacija i ocenu adekvatnosti strategije. Autori predlažu da računovođe mogu imati značajnu ulogu u olakšavanju strategijskih akcija menadžera kroz "dizajn i implementaciju” efektivnih strategijskih sistema merenja performansi. Mapa strategije omogućava menadžerima da filtriraju strategijski irelevantne informacije. Osim toga, model BSC povećava razumevanje menadžera strategijskih implikacija eksternih poslovnih trendova (Cheng \& Humphreys, 2012, 918-920).

A. A. Mohamed i T. Jones (2014, 1-22) istraživali su vezu između tehnika strategijskog upravljačkog računovodstva, kao što je $\mathrm{ABM}$, na profitabilnost preduzeća i predlažu jedan holistički model profitabilnosti baziran na interaktivnom $i$ reverzibilnom odnosu između uzročnika troškova, uzročnika aktive i uzročnika prihoda preduzeća. Osim toga, dotični model fokusira se na balansu između finansijskih i nefinansijskih informacija u upravljanju profitabilnošću. Takav jedan model identifikuje strategijske informacije o tome gde preduzeća kreiraju profit i gde preusmeravaju resurse $u$ cilju povećanja dugoročne profitabilnosti preduzeća. M. Bourne, M. Kennerley i M. Franco-Santos (2005, 373-395) u svom istraživanju istakli su značaj interaktivne primene 
merila performansi, kao i da merenje performansi zavisi od mnogih kontekstualnih i procesnih faktora.

A. S. Maiga, A. Nilsson i F. A. Jacobs $(2014,85)$ ocenili su efekat interakcije sistema kontrole troškova, kao što je $A B C$, i integracije informaciono-komunikacionih tehnologija na finansijske performanse. Rezultati studije podržavaju teorijske argumente. Iako glavni efekti integracije informaciono-komunikacionih tehnologija i sistema kontrole troškova na finansijske performanse nije značajan, njihov efekat integracije ukazuje na značajan pozitivan efekat na finansijske performanse. Značaj ove studije je upravo $u$ integrativnom posmatranju ABC-a i informacionokomunikacionih tehnologija na finansijske performanse. Ranije je analiziran izolovan uticaj obračuna troškova po aktivnostima i informacionokomunikacionih tehnologija na finansijske performanse.

C. X. Chen $(2015,67)$ diskutuje o testiranju strategije pomoću višestrukih merila performansi u BSC-u. Interna merila performansi ukazuju blagovremeno na probleme sa strategijom i omogućavaju identifikovanje gde i zašto strategija nije uspela.

M. Odar, M. Kavčič i M. Jerman $(2012,445)$ dokazuju da preduzeća u Republici Sloveniji uglavnom koriste tradicionalne modele merenja performansi. Savremene sisteme merenja performansi povremeno koriste. Autori ističu, takođe, da primena sistema merenja performansi zavisi od različite veličine preduzeća. Mala preduzeća skoro da se isključivo oslanjaju na tradicionalne modele, dok velika preduzeća imaju razvijenije modele i primenjuju neke savremene modele.

V. Domanović (2009) istražuje mogućnosti i efekte primene ABM-a i BSC-a u preduzećima u Republici Srbiji i zaključuje da u Republici Srbiji mali broj preduzeća primenjuje model BSC i ABM. Nasuprot, preduzeća uglavnom primenjuju tradicionalni model upravljanja troškovima i tradicionalnu budžetsku kontrolu. Kao razlog tome, menadžeri, uglavnom, ističu visoke troškove uvođenja i primene odgovarajućih informaciono-komunikacionih tehnologija $u$ procesu implementacije BSC-a i ABM-a. Preduzeća u kojima je došlo do priliva stranog kapitala, primenjuju model
BSC kao model strategijske kontrole i upravljanja performansama i koriste informacije iz ABC-a za izgradnju istog. Takva preduzeća ostvaruju bolju strategijsku kontrolu, primenjuju bolje podsticajne mehanizme zaposlenih, identifikuju individualnu i sektorsku odgovornost, a što doprinosi unapređenju efikasnosti preduzeća u budućem periodu. V. Domanovic (2013) ispituje efektivnost merenja performansi u uslovima savremenog poslovnog okruženja na osnovu empirijskih istraživanja različitih autora i na osnovu sprovedenog originalnog empirijskog istraživanja $u$ renomiranim preduzećima u Republici Srbiji. V. Domanovic (2013) zaključuje da se efektivnost sistema merenja performansi može posmatrati kroz dve dimenzije $\mathrm{i}$ to preko ishoda povezanih sa performansama preduzeća i ishoda povezanih sa zaposlenima. Sistem merenja performansi, konkretno BSC, treba da se koristi kao instrumentarijum upravljanja $u$ cilju motivacije zaposlenih, implementacije strategije i realizacije ciljeva, tj. kao instrumentarijum strategijske kontrole i kontrole upravljanja (Domanovic, 2013, 43).

M. Todorovic, Dj. Kalicanin i A. Nojkovic (2015, 45-58) ispituju prakse merenja performansi u preduzećima u Republici Srbiji. Autori nalaze da 18.8\% analiziranih preduzeća primenjuje BSC i to različite tipove BSC-a. Najjednostavniji tip kombinuje finansijska i nefinansijska merila, drugi tip podrazumeva izradu strategijskih mapa, a treći povezuje sisteme kompenzacija sa BSC-om. Autori, takođe, ističu da je primena savremenih modela merenja performansi, kao što je BSC, olakšana uvođenjem i primenom odgovarajućih softvera koji su obično veoma skupi za domaća preduzeća. Uvođenje i primena savremenih modela merenja performansi zavisi od veličine, nivoa internacionalizacije i profitabilnosti preduzeća (Todorovic et al, 2015, 53).

\section{ZAKLJUČAK}

Savremeno poslovno okruženje nameće potrebu za uvođenjen novina $u$ procesu definisanja $i$ implementacije strategije i u procesu upravljanja dugoročnom efikasnošću preduzeća. U tom kontekstu, uvode se inovacije u domenu strategijskog 
menadžmenta i upravljačkog računovodstva. Kao dve najistaknutije menadžerske inovacije su Usklađena lista rezultata i Upravljanje zasnovano na aktivnostima. Od posebnog značaja je njihova komplementarnost i integrativna primena.

Rezultati istraživanja potvrđuju polaznu hipotezu da postoji visoka pozitivna korelacija između Usklađene liste rezultata i Upravljanja zasnovanog na aktivnostima, s jedne strane, i strategije preduzeća, s druge strane. Naime, što je bolje izgrađena Usklađena lista rezultata, i što je rafiniranije Upravljanje zasnovano na aktivnostima, to su veće šanse da se definisana strategija dosledno sprovede i da se realizuju očekivani i više nego očekivani ekonomski efekti njene primene. Osim toga, ovi koncepti nude mogućnosti signaliziranja eventualnog neuspeha primene definisane strategije, identifikovanja uzroka odstupanja od utvrđenih standarda, na osnovu čega se mogu definisati korektivne akcije i unaprediti efikasnost preduzeća. Dinamizam okruženja je kritičan faktor koji značajno utiče na vezu između strategijskih sistema merenja performansi i performansi u smislu da je jaka pozitivna veza u stabilnom okruženju, što slabi u uslovima dinamičnog okruženja.

Imajući $u$ vidu rezultate brojnih istraživanja na temu povezanosti inovacija upravljanja - Usklađene liste rezultata i Upravljanja zasnovanog na aktivnostima i efikasnosti preduzeća, i respektujući sva njihova ograničenja, generalni je zaključak da između njih postoji pozitivna korelacija. Naime, istraživanja su pokazala da su ona preduzeća koja su implementirala Usklađenu listu rezultata i Upravljanje zasnovano na aktivnostima poboljšala svoje finansijske performanse - stopu neto rentabilnosti, prinos na investicije i slično. Pa ipak, ne treba izgubiti iz vida činjenicu da je bilo i drugačijih zaključaka u smislu da između ovih koncepata postoji negativna korelacija. U prilog tome je činjenica da proces implementacije ovih koncepata iziskuje visoke troškove, te stoga, za neka preduzeća male ekonomske snage, uvođenje i primena ovih inovacija nije ekonomski opravdana, što se utvrđuje analizom troškova i koristi. Naime, preduzeće u savremenom poslovnom okruženju mora napraviti pravu „,kombinaciju tradicionalnih merila performansi, da ih podrži Web analitikom, i poveže sa vizijom i strategijom, kako bi se proizveo holistički pogled na organizaciju". Polazeći od zahteva koje pred savremeno preduzeće nameću strategijski i operativni menadžment, a $u$ cilju uspešne implementacije Usklađene liste rezultata i Upravljanja zasnovanog na aktivnostima, potrebno je ove sisteme upravljanja i merenja automatizovati.

Postoje, takođe, indicije da uslovi koji omogućavaju primenu obračuna troškova po aktivnostima (,,sofistikacija informaciono-komunikacionih tehnologija, odsustvo viška kapaciteta i konkurentno okruženje") utiču na njegovu efikasnost. Postoji dokaz da su prethodno korišćena merila uspeha obračuna troškova po aktivnostima, zadovoljstvo sa obračunom troškova po aktivnostima i finansijske koristi od obračuna troškova po aktivnostima, prognozeri poboljšanja finansijskih performansi. Konačno, nijedna studija u datom vremenskom periodu ne može definitivno da odredi uzročnost. Buduća istraživanja mogla bi sprovoditi longitudinalne studije koje istražuju poboljšanje $u$ performansama $u$ preduzeću pre i nakon implementacije Upravljanja zasnovanog na aktivnostima.

Naučni doprinos istraživanja ogleda se $\mathrm{u}$ boljem osvetljavanju komplementarnosti i integrativne primene menadžerskih inovacija, kao što su Usklađena lista rezultata i Upravljanje zasnovano na aktivnostima. U literaturi su menadžerske inovacije, uglavnom, tretirane izolovano ukazujući na ograničenja i nedostatke primene istih, ali malo pažnje je posvećeno njihovoj integrativnoj primeni. Za savremena preduzeća od posebne je važnosti ne samo da primenjuju pojedine menadžerske inovacije, već da pokušaju da iskoriste prednosti više menadžerskih inovacija. Rezultati istraživanja mogu poslužiti i kao smernice menadžerima kako integrativna primena Usklađene liste rezultata i Upravljanja zasnovanog na aktivnostima doprinosi uspešnijoj implementaciji strategije i boljim finansijskim performansama preduzeća.

Značajno je, ipak, ukazati na sledeća ograničenja sprovedenog istraživanja. Pre svega, u radu su razmatrana samo dva najistaknutija modela merenja i upravljanja performansama, Usklađena lista rezultata i Upravljanje zasnovano na aktivnostima, u savremenom poslovnom okruženju. U literaturi iz 
sfere poslovne ekonomije i menadžmenta, upravljačkog računovodstva i strategijskog menadžmenta razlikuju se brojni modeli merenja i upravljanja performansama o kojima ovde nije bilo reči. U tom kontekstu, značajno je posmatrati integrativnu primenu i drugih modela upravljanja performansama. Osim toga, $u$ radu su razmatrani samo efekti Usklađene liste rezultata i Upravljanja zasnovanog na aktivnostima na strategiju i efikasnost preduzeća. Nisu razmatrani efekti na motivaciju zaposlenih, stimulaciju i nagrađivanje zaposlenih. Treće, $u$ literaturi ne postoje novija istraživanja na temu integrativne veze izmeđe Usklađene liste rezultata i Upravljanja zasnovanog na aktivnostima i efekata njihove integrativne primene na strategiju i efikasnost preduzeća. Stoga, ubuduće istraživanje bi moglo biti usmereno na empirijsko istraživanje uticaja integrativne primene alternativnih savremenih modela merenja performansi $u$ preduzećima u Republici Srbiji.

\section{ZAHVALNICA}

Ovaj rad je deo Projekta interdisciplinarnih istraživanja (br. 41010) koji finansira Ministarstvo prosvete, nauke i tehnološkog razvoja Republike Srbije.

\section{REFERENCE}

Adler, W. R. (2011). Performance management and organizational strategy: how to design systems that meet the needs of confrontation strategy firms. British Accounting Review, 43(4), 251-263. doi: 10.1016/j.bar.2011.08.004

Anthony, R., \& Govindarajan, V. (2007). Management Control Systems. New York, NY: McGraw-Hill/Irwin.

Atkinson, A. A., Balakrishnan, R., Booth, P., Cote, M. J., Groot, T., Malmi, T., Roberts, H., Uliana, E., \& Wu, A. (1997). New directions in management accounting research. Journal of Management Accounting Research, 9, 79-108.

Bisbe, J., \& Malagueño, R. (2012). Using strategic performance measurement systems for strategy formulation: Does it work in dynamic environments? Management Accounting Research, 23(4), 296-311. http://dx.doi.org/10.1016/j.mar.2012.05.002

Blocher, E. J., Chen, H. K., Cokins, G., \& Lin, T. W. (2005). Cost
Management: a Strategic Emphasis. New York, NY: McGrawHill/Irwin.

Bourne, M., Kennerley, M., \& Franco-Santos, M. (2005). Managing through measures: A study of impact on performance. Journal of Manufacturing Technology Management, 16(4), 373-395. http://dx.doi.org/10.1108/17410380510594480

Brignall, S., \& Ballantine, J. (2004). Strategic enterprise management systems: new directions for research. Management Accounting Research, 15(2), 225-240. doi:10.1016/j. mar.2003.10.003

Cagwin, D., \& Bouman, M. J. (2002). The association between activity-based costing and improvement in financial performance. Management Accounting Research, 13(1), 1-39. doi: 10.1006/mare.2001.0175

Chen, C. X. (2015). Discussion of testing strategy with multiple performance measures: Evidence from a BSC at Store24. Journal of Management Accounting Research, 27(2), 67-73. doi: 10.2308/jmar-51157

Cheng, M. M., \& Humphreys, K. A. (2012). The differential improvement effects of the strategy map and scorecard perspectives on managers' strategic judgments. The Accounting Review, 87(3), 899-924. doi: 10.2308/accr-10212

Chenhall, R. H. (2003). Management control systems design within it organizational context: Findings form contingencybased research and directions for the future. Accounting, Organizations and Society, 28(2-3), 127-168.

Davis, S., \& Albright, T. (2004). An investigation of the effect of BSC implementation on financial performance. Management Accounting Research, 15(2), 135-153. doi: 10.1016/j. mar.2003.11.001

Domanović, V. (2009). Usklađena lista rezultata $i$ upravljanje zasnovano na aktionostima u funkciji unapređenja efikasnosti preduzeća. Neobjavljena doktorska disertacija. Ekonomski fakultet Univerziteta u Beogradu, Beograd, Republika Srbija.

Domanovic, V. (2013). The effectiveness of performance measurement in terms of the contemporary business environment. Economic Horizons, 15(1), 33-46. doi: 10.5937/ ekonhor1301031D

Fahy, M. (2001). Strategic Enterprise Management Systems: Tools for the $21^{s t}$ Century. London, UK: The Chartered Institute of Management Accountants.

Ittner, C. D., \& Larcker, D. F. (1998). Are nonfinancial measures leading indicators of financial performance? An analysis of customer satisfaction. Journal of Accounting Research, 36(3), 1-35. doi: $10.2307 / 2491304$ 
Ittner, C., Larcker, D. F., \& Randall, T. (2003). Performance implications of strategic performance measurement in financial services firms. Accounting, Organizations and Society, 28(7-8), 715-741. doi: 10.1016/S0361-3682(03)00033-3

Kaličanin, Đ., \& Knežević, V. (2013). Activity-based costing as an information basis for an efficient strategic management process. Economic Annals, 58(197), 95-119. doi: 10.2298/ EKA1397095K

Kaplan, R. S., \& Norton, D. (1992). The BSC - measures that drive performance. Harvard Business Review, 70(1), 71-79.

Kaplan, R., \& Norton, D. (2001). The Strategy Focused Organization - How BSC Companies Thrive in the New Business Environment. Boston, USA: Harvard Business School Press.

Kennedy, T., \& Affleck-Graves, J. (2001). The impact of activitybased costing techniques on firm performance. Journal of Management Accounting Research, 13(1), 19-45. doi: http:// dx.doi.org/10.2308/jmar.2001.13.1.19

Lawson, R., Stratton, W., \& Hatch, T. (2004). Automating the BSC. CMA Management, 77(9), 39-43.

Maiga, S. A., \& Jacobs, F. A. (2003). BSC, activity-based costing and company performance: An empirical analysis. Journal of Managerial Issues, 15(3), 283-301.

Maiga, A. S, Nilsson, A., \& Jacobs, F. A. (2014). Assessing the interaction effect of cost control systems and information technology integration on manufacturing plant financial performance. The British Accounting Review, 46(1), 77-90. http://dx.doi.org/10.1016/j.bar.2013.10.001

Malina, M. A., Selto, F. H. (2001). Communicating and controlling strategy: An empirical study of the effectiveness of the BSC. Journal of Management Accounting Research, 13(1), 47-90. doi: http://dx.doi.org/10.2308/jmar.2001.13.1.47

Micheli, P., Mura, M., \& Agliati, M. (2011). Exploring the roles of performance measurement systems in strategy implementation: The case of a highly diversified group of firms. International Journal of Operations $\mathcal{E}$ Production Management, 31(10), 1115-1139. http://dx.doi. org/10.1108/01443571111172453

Mohamed, A. A., \& Jones, T. (2014). Relationship between strategic management accounting techniques and profitability - A proposed model. Measuring Business Excellence, 18(3), 1-22. http://dx.doi.org/10.1108/MBE-04-20130023

Niven, R. (2002). BSC Step by Step: Maximizing Performance and Maintaining Results. John Wiley \& Sons, Inc.

Norton, D. (1999). SAP Strategic Enterprise Management: Translating Strategy into Action: The BSC. SAP AG: SEM Product Management.

Otley, D. (1999). Performance management: A framework for management control systems research. Management Accounting Research, 10(4),363-382. doi:10.1006/mare.1999.0115

Odar, M., Kavčič, M., \& Jerman, M. (2012). Performance measurement systems: Empirical evidence from Slovenia. Economic Research, 25(2), 445-464. doi: 10.1080/1331677X.2012.11517517

Shields, M. D. (1995). An empirical analysis of firms' implementation experiences with activity-based costing. Journal of Management Accounting Research, 7, 148-166.

Shields, D. M., \& McEwen, M. A. (1996). Implementing activity-based costing systems successfully. Journal of Cost Management, Winter, 15-22.

Stojanović Aleksić, V. (2008). Promena organizacione kulture kao jedna od ključnih pretpostavki uspešnog sprovođenja organizacionih promena u procesu tranzicije. U: I. Rosić i V. Leković, (Ur.), Institucionalne promene kao determinanta privrednog razvoja Srbije (str. 150-159). Kragujevac, Republika Srbija: Ekonomski fakultet Univerziteta u Kragujevcu.

Swamy, R. (2002). Strategic performance measurement in the new millennium. CMA Management, 76(3), 44-47.

Tayler, W. B. (2010). The BSC as a strategy-evaluation tool: The fffects of implementation involvement and a causal-chain focus. The Accounting Review, 85(3), 1095-1117. doi: 10.2308/ accr.2010.85.3.1095

Todorovic, M., Kalicanin, Dj., \& Nojkovic, A. (2015). Practices of performance measurement in companies in the Republic of Serbia. Economic Horizons, 17(1), 45-58. doi: 10.5937/ ekonhor1501045T

Primljeno 5. juna 2016, nakon dve revizije, prihvaćeno za publikovanje 22. avgusta 2016. 
Violeta Domanović je vanredni profesor na Ekonomskom fakultetu Univerziteta u Kragujevcu. Doktorirala je na Ekonomskom fakultetu Univerziteta u Beogradu, iz oblasti poslovne ekonomije. Ključne oblasti njenog naučnog istraživanja su merenje i upravljanje performansama preduzeća.

\title{
THE EFFECTS OF THE INTEGRATED APPLICATION OF BSC AND ABM TO ENTERPRISE STRATEGY AND EFFICIENCY
}

\author{
Violeta Domanovic \\ Faculty of Economics, University of Kragujevac, Kragujevac, The Republic of Serbia
}

\begin{abstract}
The shortcomings of an individual application of some managerial innovation models in the domain of management accounting and strategic management in the modern business environment made research into the complementary and integrated application of managerial innovation models inevitable. The aim of the research is to show that the complementary use of the BSC and the ABM in managing enterprise strategy and efficiency eliminates the shortcomings of their individual application. The paper specifies the effects of the application of the BSC and the ABM on the enterprise strategy, particularly emphasizing the role of ICT in the course of implementation, and presents the results of the empirical research into the correlation of the BSC and the ABM regarding the strategy and efficiency of an enterprise. Despite possible problems and limitations, a proper synergic use of respective managerial innovations enables a better implementation of the defined strategies and improves the efficiency of the enterprise in the long run.
\end{abstract}

Keywords: BSC, ABM, strategy, information and communication technologies, enterprise efficiency

JEL Classification: M10, M21, M41 